Hydrol. Earth Syst. Sci. Discuss., 6, 3089-3141, 2009 www.hydrol-earth-syst-sci-discuss.net/6/3089/2009/ (C) Author(s) 2009. This work is distributed under the Creative Commons Attribution 3.0 License.
Hydrology and Earth System Sciences Discussions

Papers published in Hydrology and Earth System Sciences Discussions are under open-access review for the journal Hydrology and Earth System Sciences

\title{
Impacts of climate change scenarios on runoff regimes in the southern Alps
}

\section{S. Barontini ${ }^{1}$, G. Grossi ${ }^{1}$, N. Kouwen ${ }^{2}$, S. Maran ${ }^{3}$, P. Scaroni ${ }^{1}$, and R. Ranzi ${ }^{1}$}

${ }^{1}$ DICATA, Department of Civil Architectural Environmental and Land planning Engineering, University of Brescia, Brescia, Italy

${ }^{2}$ Department of Civil and Environmental Engineering, University of Waterloo, Waterloo, Canada

${ }^{3}$ CESI RICERCA S.p.A., Milan, Italy

Received: 7 February 2009 - Accepted: 26 March 2009 - Published: 7 April 2009

Correspondence to: S. Barontini (barontin@ing.unibs.it)

Published by Copernicus Publications on behalf of the European Geosciences Union.

\section{HESSD}

6, 3089-3141, 2009

Climate change and runoff regimes in the southern Alps

S. Barontini et al.

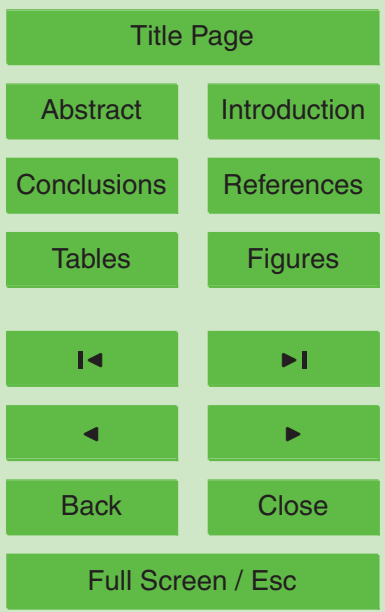

Printer-friendly Version

Interactive Discussion 


\section{Abstract}

The potential impact of climate change scenarios on the runoff regime in the Italian Alpine area was investigated. A preliminary analysis of the output of three Global Circulation Models (PCM, HADCM, ECHAM) was needed to select IPCC-based scenarios 5 for the 2000-2099 period. Two basins, 1840 and $236 \mathrm{~km}^{2}$ in size, respectively, and with different glaciated areas and storage capacity of reservoirs were selected as case studies. The PCM model, the one capable to better reproduce the observed rainfall regime in the investigated area, with the IPCC SRES A2 scenario was adopted for the meteorological forcing. On average for the two basins, an increase of annual precipitation of of this century compared to present increase of $1.1^{\circ} \mathrm{C}$ in 2050 and $2.4^{\circ} \mathrm{C}$ for 2090 . Because of the coarse resolution of the climate models' output, the statistics of the simulated rainy days and daily precipitation were adapted to the scale of the two selected basins using a modified version of of intermittent fully developed turbulence. As regards to land cover, glaciated areas are decreased, in the future scenarios, according to the Kuhn's concept of equilibrium line adaptation to climate fluctuations. The tree-line altitude is increased, according to the observed trend since the end of the Little Ice Age: thus boundary conditions for evapotranspiration changed. The resulting meteorological variables and hydrological parameters were used to run the WATFLOOD hydrological model in order to assess the changes of runoff regimes in the two watersheds. A decrease of about $7 \%$ of annual runoff volume for the 2050 scenario and of $13 \%$ for the 2090 scenario was estimated, on average, at the outlet of the Oglio river basin, the largest one. In the smaller Lys basin, where the glaciated area is $8 \%$ of the total area, the annual runoff is foreseen to decrease by about 3\% (for the 2050 scenario) and 14\% at the end of this century. Also the runoff regime changes are significant, with an increase of spring melt and a decrease of summer and autumn runoff. No clear evidence is found for changes in the

HESSD

6, 3089-3141, 2009

\section{Climate change and runoff regimes in the southern Alps}

S. Barontini et al.

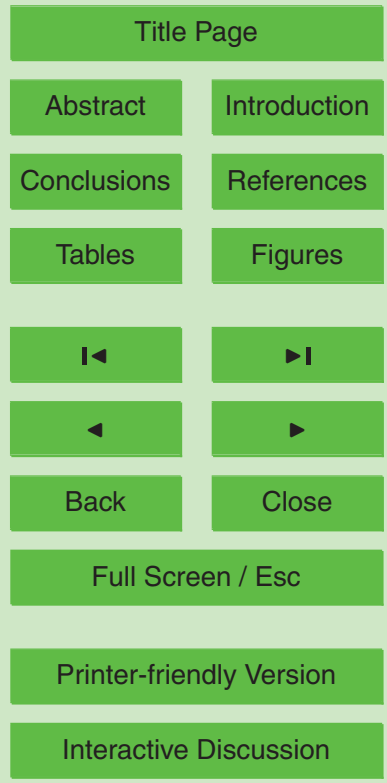

Interactive Discussion 


\section{HESSD}

\section{Introduction}

The perception that the Earth is experiencing a fast climate transition, characterised by global warming and changes in the precipitation pattern, is today accepted by most 5 scientists (e.g. Oreskes, 2004; Lovell, 2006), with some exceptions (e.g. Gerhard, 2004, 2006). On the basis of experimental evidences, the IPCC 4th Assessment report (IPCC, 2007a) and the recent report by Bates et al. (2008) about climate change impact on water resources depict, in summary, the following situation for the Earth's climate, hydrosphere and criosphere:

- an increase of $0.13^{\circ} \mathrm{C}$ per decade is observed for the surface temperature at the global scale over the last 50 years, the double of the last century's trend, but less than the $0.2^{\circ} \mathrm{C}$ per decade observed at the end of the century;

- annual precipitation is increasing in North and South America, northern Europe, northern and central Asia and is decreasing over the Sahel region, the Mediteranean, southern Africa and part of southern Asia;

- Northern Hemisphere snow cover observed by satellite over the 1966 to 2005 period decreased in every month except November and December, with a stepwise drop of $5 \%$ in the annual mean in the late 1980s (IPCC, 2007b);

- glaciers are retreating almost worldwide with a global average annual mass loss of more than half a metre water equivalent during the decade of 1996 to 2005 (UNEP-WGMS, 2008), twice the ice loss of the previous decade and over four times the rate of the decade from 1976 to 1985.

More complex patterns are observed at the regional scale, depending on changes of the local atmospheric circulation. For instance, concerning precipitation over the

\section{Climate change and runoff regimes in the southern Alps}

S. Barontini et al.

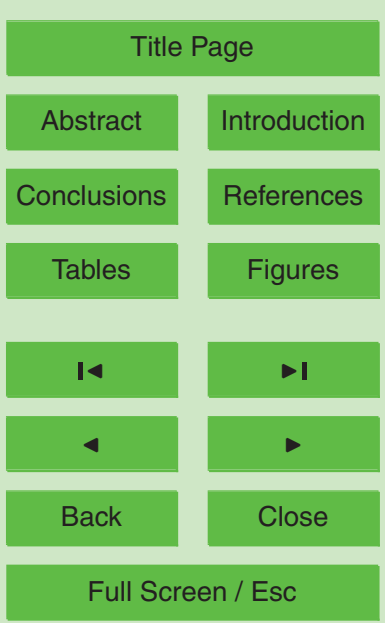

Printer-friendly Version

Interactive Discussion 
Alps, a $90 \%$-significant increase of annual precipitation by $1.6 \%$ per decade in the North-Western part and a decrease of $0.5 \%$ per decade in the South-Eastern part was observed on the $1950-2000$ period. An increase of $0.25^{\circ} \mathrm{C}$ vs. an increase of $0.17^{\circ} \mathrm{C}$ per decade is observed in the same subregions (Auer et al., 2007).

5 On the basis of Global Circulation Model's (GCM) scenarios the IPCC $(2007 a, b)$ report confirms, for the future, the observed experimental trends and projects for the current century, at the global scale:

- a global surface air warming ranging from $0.6^{\circ} \mathrm{C}$ to $4.0^{\circ} \mathrm{C}$ at $2090-2099$ relative to 1980-1999;

- globally averaged mean water vapour, evaporation and precipitation are projected to rise with an increase of mean annual precipitation at the global scale ranging from $1.3 \%$ to $4.5 \%$, depending on greenhouse gases (GHG) emission scenario over the same period;

- at the end of the 21 st century the projected reduction of snow cover in the Northern Hemisphere ranges between $9 \%$ to $17 \%$;

- the sensitivity of total glaciers and ice-caps specific mass balance to temperature rise is expected to range from -0.32 to $-0.41 \mathrm{~m} \mathrm{a}^{-1}{ }^{\circ} \mathrm{C}^{-1}$ corresponding to a specific mass loss ranging from some tens to about $100 \mathrm{~m}$ over the century.

At the regional scale, as an example, similar temperature trends were outlined for the Alpine region after an analysis of recent IPCC AR4 scenarios by Faggian and Giorgi (2007), a result confirmed by our study.

More uncertain is the impact on runoff that could have relevant feedbacks, in the near future, on the water management policies (e.g. Parry et al., 1998, 2001) and engineering design. No clear signals of runoff changes at the global scale are documented by the IPCC (Bates et al., 2008), although several studies at the regional scale report about significant variations on a statistical basis in the 20th century. As a balance between precipitation increase and evapotranspiration changes for the current century

HESSD

6, 3089-3141, 2009

Climate change and runoff regimes in the southern Alps

S. Barontini et al.

Title Page

Abstract

Introduction

Conclusions

Tables

References

Figures

14

4

Back

Close

Full Screen / Esc

Printer-friendly Version

Interactive Discussion 
Labat et al. (2004) estimate an increase of $4 \%$ global amount of runoff each $1^{\circ} \mathrm{C}$ of temperature increase, even if Legates et al. (2005) do not agree on their conclusions.

Concerning the impact on the hydrological cycle and runoff, the temperature rise will reduce the fraction of precipitation in the form of snow vs. rain. An increase of winter 5 runoff, with respect to the total annual amount, is therefore expected. Snow and ice melt runoff initiation is expected to anticipate but its total volume depends also on the adaptation to a changed climate of the areal extent of snow and ice fields. Summer melt runoff should decrease and autumn freezing will start later. With respect to runoff particularly sensitive will therefore be the regions where snowfall is a significant frac10 tion of precipitation and melt runoff relevant. It is considered a "very robust finding" (Bates et al., 2008) that, in a warming scenario, changes in the runoff regime will be observed particularly in those regions where the ice- and snow-cover are important for the runoff production. Many Authors recently pointed out this aspect for various basins characterised by more or less strong glacial- and nival-influence on the runoff regime 15 (e.g. Bobba et al., 1997; Seidel et al., 1998; Pfister et al., 2004; Krysanova et al., 2005; Schaefli et al., 2007).

However the total amount of runoff is also deeply influenced by the evapotranspiration losses, which locally depend on a number of factors as the total amount of precipitation and its regime, the air temperature and energy exchanges, the climatic feedback on the self-vegetation and anthropogenic effects on the forest cover. The vegetation species in fact can put into action a wide number of different mechanisms in order to react to a climate change (e.g. Walther et al., 2002; Beniston, 2000, for a review). As an example Huntley (1991) focuses on three main kinds of reactions of the vegetation, at the species level, to a climate forcing: genetic adaptation, biological invasion, due also related to the reduction of the area when the altitude increases, can significantly change the equilibium state of the species in the system. While evaporation from water surfaces and dry areas will increase in a global warming, there is a lack of scientific consensus about the transpiration losses, which might increase because of the higher

\section{HESSD}

6, 3089-3141, 2009

\section{Climate change and runoff regimes in the southern Alps}

S. Barontini et al.

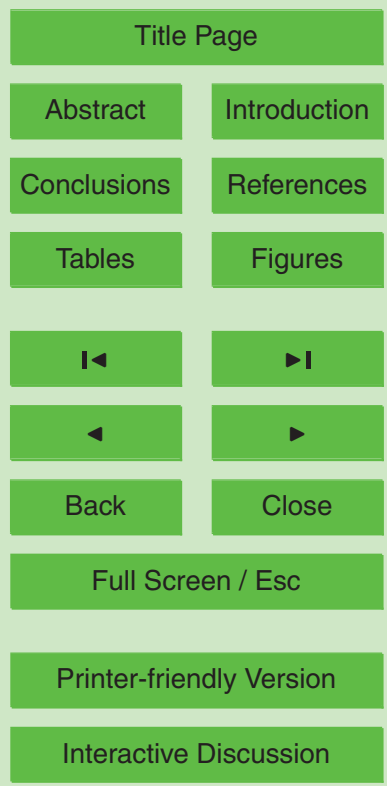

Interactive Discussion 
energy available but also decrease as a negative feedback due to the enhanced stomatal resistance with the rising atmospheric carbon dioxide concentration. As it was pointed out by Bates et al. (2008), only a few experimental studies are nowadays available in order to formulate a robust hypothesis on the effect of a climate change scenario 5 on the evapotranspiration losses in the water balance.

So runoff changes are likely to be the most uncertain component of the hydrological cycle, especially in mountain areas with transient and seasonal snow cover. Therefore, with the aim of better understanding the effects of climate change scenarios on the runoff regime and water availability in temperate mountain areas, we developed 10 a methodology, based on a hydrological continuous and semi-distributed simulation forced by observations and GCM scenarios for twenty years time windows centred on 2050 and 2090. In our applications we will focus our attention on downscaling of precipitation and temperature and on the feedback of the increase of mean annual temperature on the self-vegetation and glacier's extent. Our procedure was applied to 15 two meso-scale Alpine basins (1840 and $236 \mathrm{~km}^{2}$ in size) with different glaciated areas and reservoirs' storage, located in the Po catchment in northern Italy. The runoff regime of the two basins selected are representatative of those of the Sarca-ChieseOglio and Toce-Dora Baltea river systems, respectively, which contribute to about $20 \%$ of the national hydropower production. This last was $47.7 \mathrm{TWh} \mathrm{a}^{-1}$ on average in the 2001-2005 period representing about $16 \%$ of the national production of energy.

In the second section the target areas investigated are described together with the criteria adopted for the selection of the most suitable GCM and projected scenarios. In the third section the downscaling methods to adapt the coarse and biased GCM's daily precipitation and temperature output to the scale of the two basins are presented.

25 Then the key aspects of the hydrological model and its parameters setup, including the adaptation of vegetation and ice-covered areas to climate change, are summarised. In the fifth section major results of the simulations are presented and discussed.

\section{HESSD}

6, 3089-3141, 2009

\section{Climate change and runoff regimes in the southern Alps}

S. Barontini et al.

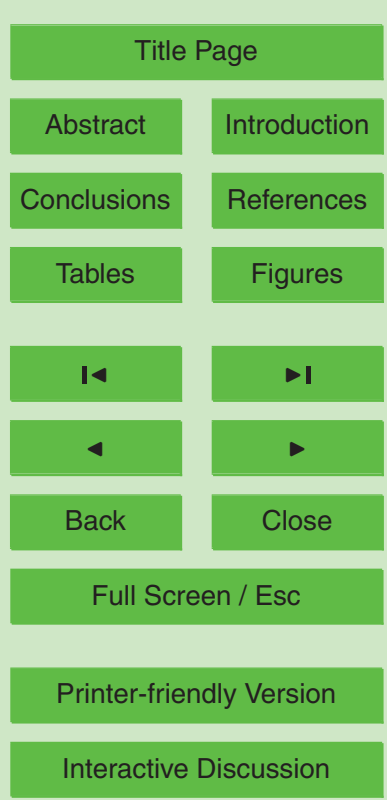




\section{GCM scenarios}

\subsection{Target areas}

6, 3089-3141, 2009

Two target areas were selected as case studies: the Oglio river basin at Sarnico $\left(1840 \mathrm{~km}^{2}\right)$, in the central Italian Alps, and the Lys river basin at Guillemore $\left(236 \mathrm{~km}^{2}\right)$, 5 in the northern Italian Alps (Fig. 1). The rationale of this choice is based on the great importance of the hydropower-plants in the two basins, with regard to the national production, and on the difference of the plant schemes. The Oglio river basin is in fact characterised by a large reservoir capacity, of about $180 \mathrm{hm}^{3}$ and about $10 \%$ of the total basin area is drained by reservoirs. On the other hand, the principal hydropower plant within the Lys catchment located at Pont St. Martin is a run-the-river type, with a negligible storage capacity. The main physiographical data of the two basins are given in Table 1. In the following a brief description of the basins is provided.

In the Oglio river basin, a lefthand tributary of the Po river, the altitude ranges between 187 ma.s.l. at Sarnico at the outlet of Lake Iseo $\left(65 \mathrm{~km}^{2}\right)$ to $3539 \mathrm{ma.s.l}$. of the Adamello peak. Due to the significant elevation range available for hydropower production, this area has been deeply exploited since the end of the 19th century and the system of dams and interlaced channels built since then is still one of the most important in Italy. The geology is characterised by significant intrusive formations and limestones. The land cover is mainly deciduous and coniferous forest up to the tree20 line altitude at about $2000 \mathrm{~m}$. Upstream, the glaciated area accounts for $10.4 \mathrm{~km}^{2}$. The precipitation regime belongs to the so-called alpine sub-litoranean type, as defined by Bandini (1931). A sub-litoranean regime, which is typical for some areas in the northern Italy, is characterised by one maximum in spring and one in autumn, with minor differences if it is alpine or appennidic. In the northern part of the basin a transition regime toward the continental type, with only one maximum in the summer, is observed. Glaciers do not significantly affect the runoff regime, which is pluvio-nival. The runoff is thus mainly influenced by snow melt in spring and by rainfall in autumn.

The Lys river basin, a lefthand tributary of the Dora Baltea river, in the major Po

\section{Climate change and runoff regimes in the southern Alps}

S. Barontini et al.

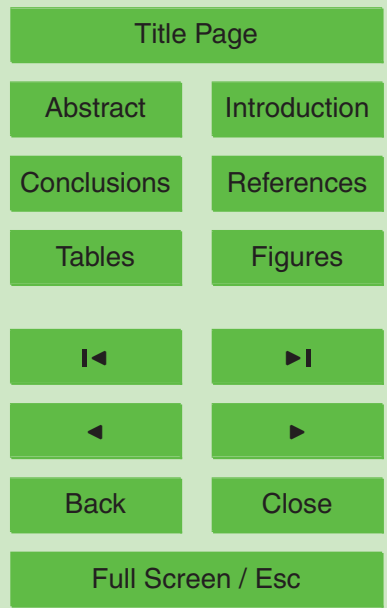

Printer-friendly Version

Interactive Discussion 
river basin, has a total area of $236 \mathrm{~km}^{2}$ at Guillemore, including an interlaced area of $31 \mathrm{~km}^{2}$ upstream the Pont St. Martin power plant. The altitude ranges from $894 \mathrm{~m}$ a.s.l. at the Guillemore dam to $4532 \mathrm{~m}$ a.s.I. of the eastern Lyskamm, a peak of the Monte Rosa massif. The geology is characterised by metamorphic rocks, as micaschist and 5 gneiss in the northern part of the basin, serpentines in the central part and gneiss in the southern. The upper rock layer is massive and pervious only if fractured. It is characterised by deciduos and coniferus forest cover up to $1500 \mathrm{~m}$ a.s.l., by larch forests up to $2100 \mathrm{~m}$ a.s.l. At higher altitudes bare outcropping rocks, adjoint to glaciers and pervious moraines, are the dominant land cover feature. The observed precipitation 10 regime is alpine sub-litoranean and the runoff regime at Guillemore is nivo-glacial with one maximum in late spring (May-June) and a minimum in winter. Within this basin, a sub-basin of $10.4 \mathrm{~km}^{2}$ mainly glaciated is gauged at Lake Gabiet (2380 m a.s.I.). Here another important hydropower plant is located. The runoff regime is of the glacial type, with the main peak in summer (June-July) due to glacier ablation, and a measured total runoff of $1064 \mathrm{~mm}$.

\subsection{Future climate scenarios}

In the Special Report on Emission Scenarios-SRES (IPCC, 2000), based on a reanalysis of previous works (see e.g. IPCC, 1994, for a comparison), the Intergovernmental Panel on Climate Change described four possible future storylines (A1, A2, B1, B2), each referring to potential causes of GHG emissions and to their possibile future dynamics. Forty different scenarios were defined based on the storylines, considering possible demographic, social and economical evolution trends and technological developments as causes for future GHG emissions. Each SRES scenario family assumes one out of the four possible storylines and "do not include additional climate initiatives, which means that no scenarios are included that explicitly assume implementation of the United Nations Framework Convention on Climate Change or emission targets defined by the Kyoto Protocol" (e.g. IPCC, 2001) which entered into force only on 16
HESSD

6, 3089-3141, 2009

\section{Climate change and runoff regimes in the southern Alps}

S. Barontini et al.

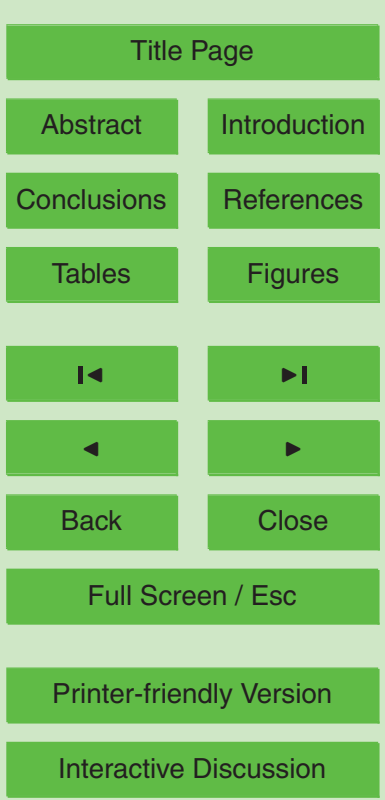


February 2005. Anyway during the past decade world's economy has rapidly changed and, also after the recent finantial crisis, it is becoming clear how difficult it is to predict future GHG concentrations resulting from any governmental decision and from the dynamics of the causes of GHG emissions.

However the four storylines and the resulting 40 scenarios still represent a realistic ensemble of the future socio-economic context the world will face. We review, in summary:

- A1 scenarios: a future world of very rapid economic growth, global population increasing in mid 21st century and rapid introduction of new and more efficient technologies. Three groups are defined as depending on the energy source which is playing the most important role, with A1FI being fossil intensive, A1T without fossil energy sources, A1B assuming a balance across all sources. As a consequence these scenarios cover a wide range of GHG emissions trajectories, thus spanning between pessimistic and optimistic, and can be globally considered as an intermediate family of "weakly pessimistic" scenarios.

- A2 scenarios: the future world's development is very heterogeneous. The population is always increasing while the technological upgrading is the slowest one, with only little international cooperation. These paradigms should exacerbate the GHG emissions so that A2 scenario is regarded to as a "pessimistic" one. By means of an expression already coined for one of the previous set of scenarios, it is sometimes defined as "Business-as-usual" (Beniston, 2004).

- B1 scenarios: population growth is as for scenarios $A 1$, but the economy is reducing the exploitation of the resources and new and more efficient technologies are applied. Accounting for the choice of global solutions for economic, social and environmental sustainability this corresponds to the "most optimistic" family of scenarios.

- B2 scenarios: local solutions to economic, social and environmental sustainability are adopted. Global population is continuously increasing, but not as fast as for

\section{HESSD}

6, 3089-3141, 2009

\section{Climate change and runoff regimes in the southern Alps}

S. Barontini et al.

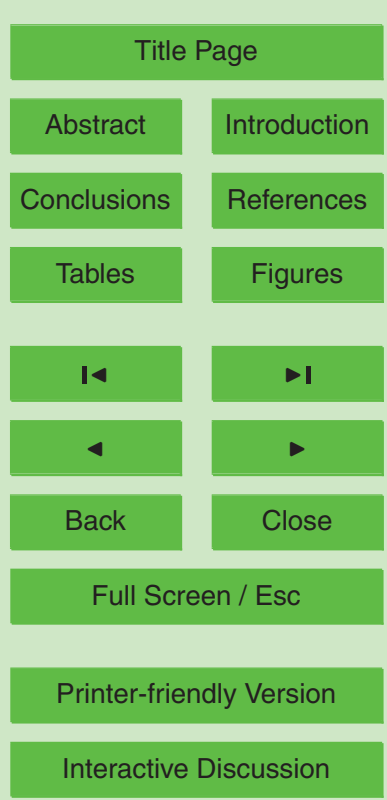


scenarios A2. The economy grows at an intermediate rate, but less technological adaptation measures are assumed. As the A1 family, B2 scenarios correspond to a "weakly pessimistic" GHG emossions projection.

\subsection{Selection of GCM models}

5 For this study three different GCM models (NCEP/NCAR-PCM, MPI-ECHAM4-OPYC3 and HADCM3-HADLEY) were initially selected, as a source of the meteorological data, within the World Climate Research Programme's (WCRP's) Coupled Model Intercomparison Project phase 3 (CMIP3) multi-model dataset (see Meehl et al., 2007, for details on the dataset). Selected data were available in the early 2005 at the IPCC Data Distribution Centre. In the following the model will be referred to as PCM, ECHAM and HADCM.

Focusing on precipitation and temperature, for which long time series of observations were available, PCM proved to be more effective than HADCM and ECHAM in reproducing the observed monthly regimes of the historical (1979-1999) validation window, as it is shown, as an example, for the Oglio river basin in Fig. 2 (on the lefthand side) and in Table 4. The observed temperature regime is referred to $1398 \mathrm{~m}$ a.s.l., the average altitude of the network which is very close to the average altitude of the basin. The GCM data, instead, are the regimes obtained as an average of the raw monthly data, referred to the height of the local grid cell which is lower, for all the models, be-

cause of the smoothed orography adopted. Once the GCM was chosen for the further applications, available daily data were used. The reason why the scenarios were built using only precipitation and temperature series is that only for these variables long time series of observations were available. In order to objectively evaluate the performances of the GCMs three different scores were computed for the re-normalised

monthly precipitation, as reported in Table 3. These are the root mean squared error of the monthly precipitation regime (M-RMSE), of the cumulative precipitation volumes (V-RMSE) and the maximum absolute error of simulated vs. observed cumulative precipitation volumes (V-MAE). As it can be seen PCM is slightly better than ECHAM in

HESSD

$6,3089-3141,2009$

\section{Climate change and runoff regimes in the southern Alps}

S. Barontini et al.

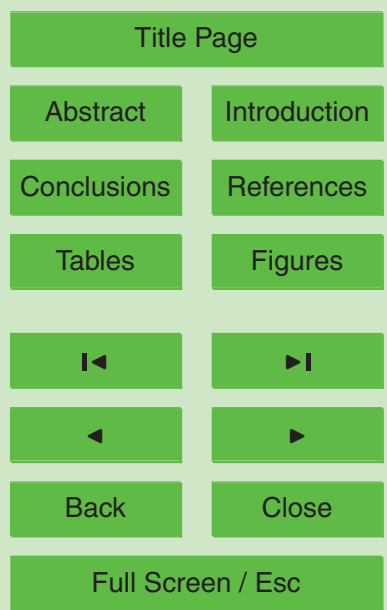

Printer-friendly Version

Interactive Discussion 
terms of V-RMSE and V-MAE, and definitively better than HADCM for all the scores. In addition Fig. 2 shows that PCM better captures some patterns of the precipitation regime, as the absolute minimum of precipitation in February and the May-June-July maximum, being the ECHAM monthly distribution too smooth. On the other hand the 5 HADCM-based regime stresses too much the importance of the summer miminum (less than one third of the observed precipitaion in August) vs. the winter one. Such a behaviour would have relevant effects on the hydrological response of the basin.

Then, three different GCM-projected scenarios were selected for two future time windows 2040-2060 and 2079-2099, with the aim of analysing future climate and en10 vironmental conditions in a time period centered at 2050 and 2090, respectively. This is close to the idea of checking the effects of potential climate change at the middle and at the end of the current century. With the aim to represent the widest range of possible hydrological responses, scenarios $A 2, B 2$ and $A 1 B$ were firstly selected to build the precipitation and air temperature forcing for the two Alpine basins. As an example of the inter-model and inter-scenario uncertainty in the precipitation projections, focusing on the Oglio river basin, the total precipitation for A2 scenario ranges from $706.4 \mathrm{~mm}$ (HADCM) to $992.2 \mathrm{~mm}$ (PCM) at the annual time scale for the 2040-2060 time window, and $B 2$ scenario total precipitation ranges from $734.5 \mathrm{~mm}$ (HADCM) to $1059.7 \mathrm{~mm}$ (ECHAM).

20 However, because of the better agreement with observations, PCM-based scenarios were chosen for this analysis. Figure 2 (on the righthand side) and Table 4 show the variability of PCM-based precipitation regimes referring to different scenarios as well as to the two selected future time windows. The annual precipitation is not strongly affected, but the change is more evident at the monthly scale (especially in the fall season) and for the end of the century. Mean annual precipitation for the PCM-A2 scenario should increase of about $3 \%$ and $2 \%$, for the Oglio and Lys basins, respectively, for the period 2050, and it should slightly increase at the end of this century compared to today's conditions. As an example for the Oglio river basin, using instead the mean annual precipitation provided by ECHAM, we see a decrease of $6 \%$ and $4 \%$ respectively

HESSD

6, 3089-3141, 2009

\section{Climate change and runoff regimes in the southern Alps}

S. Barontini et al.

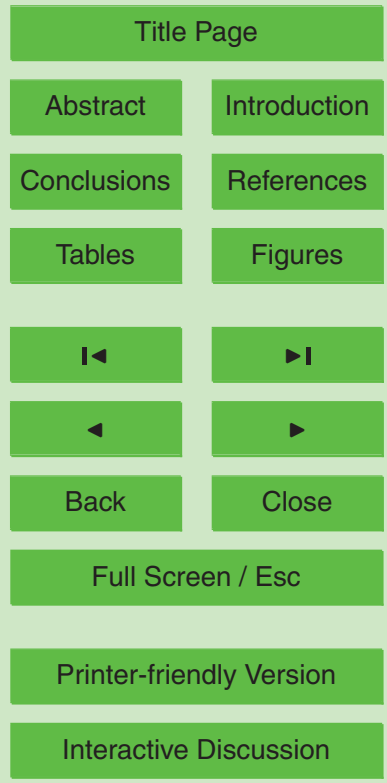

Interactive Discussion 
for the 2050- and 2090-centered A2-scenario. A strong decrease in the mean annual precipitation is indicated by HADCM-A2 scenario for the same area, of $10 \%$ and $24 \%$, respectively, for the 2050- and 2090-centered temporal windows.

The temperature regimes are represented in Table 2. Intermodel differences in mean 5 annual temperature can be in part explained also considering the different orography adopted by the models which is smoother than the actual one having the grid cell for the Oglio basin in PCM a mean altitude of $800 \mathrm{~m}$, in ECHAM of $850 \mathrm{~m}$ and of $500 \mathrm{~m}$ in HADCM, thus explaining the $1.8^{\circ} \mathrm{C}$-higher mean annual temperature in comparison with PCM. As GCM grids are very coarse, they cannot reproduce the mountain orog10 raphy especially in the Alpine region which is represented by only a few grid points. Therefore, in view of a hydrological application, we corrected the GCM temperature in order that the control scenario reproduces on average the observed historical data. The same bias should therefore apply to the future scenarios. In the A2 scenario, with regard to the nearest grid point to the Oglio river basin, an increase of the mean annual 15 temperature ranging from $1.1^{\circ} \mathrm{C}(\mathrm{PCM})$ to $2.7^{\circ} \mathrm{C}(\mathrm{ECHAM})$ is projected for $2040-2060$ with respect to the control simulation, and an increase ranging from $2.4^{\circ} \mathrm{C}(\mathrm{PCM})$ to $5.5^{\circ} \mathrm{C}$ (ECHAM) is projected for 2079-2099. Lower increases are expected within the framework of the weakly pessimistic $\mathrm{B} 2$ scenario, ranging from $1.0^{\circ} \mathrm{C}(\mathrm{PCM})$ to $2.6^{\circ} \mathrm{C}$ (ECHAM) for $2040-2060$, and from $1.7^{\circ} \mathrm{C}(\mathrm{PCM})$ to $3.8^{\circ} \mathrm{C}$ (ECHAM) projected for 2079 2099.

\section{Spatial downscaling of the PCM data}

PCM data, but also most of the other GCM-based data as well, are now available at the 1-day temporal scale that can satisfactory meet the requirements of a hydrological simulation aiming at reproducing runoff regimes on a climatological scale, as in our study. Anyway, the linear spatial scale of the grid cell, which is more than $200 \mathrm{~km}$ at latitudes of $45^{\circ} \mathrm{N}$, is not suitable for most of the hydrological applications at the mesoscale. The linear scale of the latter can be in fact considered of the order of some

HESSD

6, 3089-3141, 2009

\section{Climate change and runoff regimes in the southern Alps}

S. Barontini et al.

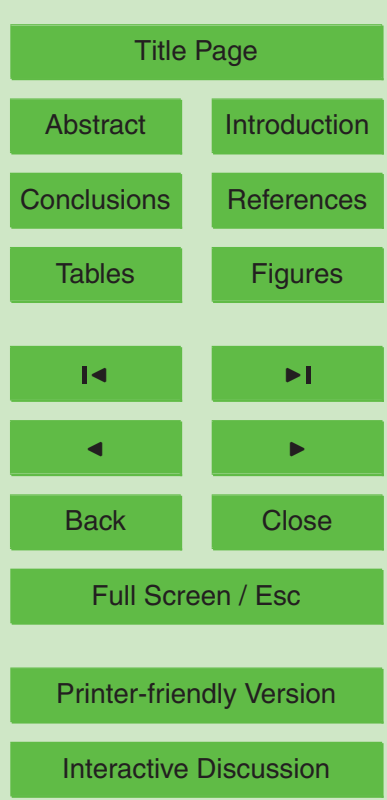


tens of kilometers. Therefore the downscaling of GCM-based meteorological data is a key aspect in the hydrological simulation forced by syntetic data.

Let us first of all focus on the precipitation data. A great number of contributions have been produced for the last two decades focused on the downscaling of GCM-based 5 meteorological data with different approaches (see e.g. Giorgi and Mearns, 1991; Wilby and Wigley, 1997; Prudhomme et al., 2002, for a review). A time-downscaling is necessary for the hydrological forcing by GCM data available at monthly or longer time scales (e.g. Burlando and Rosso, 1991; Wilby et al., 2002; Maurer and Hidalgo, 2008) or to project information on extreme runoff events (e.g. Burlando and Rosso, 2002a,b, 10 for the Arno river basin in central Italy), but it is not needed as the temporal scales of the hydrological and meteorological simulations are similar. Otherwise, even for climatology-oriented hydrological simulations, GCM-based forcing data still require the application of a spatial downscaling procedure through the spatial scales of rainfall fields before they can be used, because of the non-linearity of the runoff response, the 15 spatial intermittency of the precipitation fields and the hyerarchical structure of rainfall fields (Waymire et al., 1984; Cowpertwait et al., 1996), which cannot be reproduced by GCMs. In fact, the GCM-precipitation being the spatial average on a wide grid cell, local statistics of dry days are not respected and a large number of low intensity rainy events is not able to produce a realistic runoff extimate. Moreover the precipitation fields in mountain regions are affected by regional climatic patterns, orographic effects and local convective phoenomena (as an example, some results on this topic are discussed by Ranzi et al., 1999, and Bacchi and Kottegoda, 1995, for the central Italian Alps). The trough of the annual precipitation measured in the central Po Valley, and its increase in the piedmont areas are examples of the concurrent effect of climatic and orographic patterns (Brunetti et al., 2009). Therefore, taking into account that the best agreement between the simulated and observed monthly precipitation regime was our criterion to select the reference GCM, a spatial downscaling procedure of the PCM precipitation was set with the following properties: the observed statistics of (i) the annual amount of precipitation, (ii) the expected number of the dry days, (iii) the spatial cor-

\section{HESSD}

6, 3089-3141, 2009

\section{Climate change and runoff regimes in the southern Alps}

S. Barontini et al.

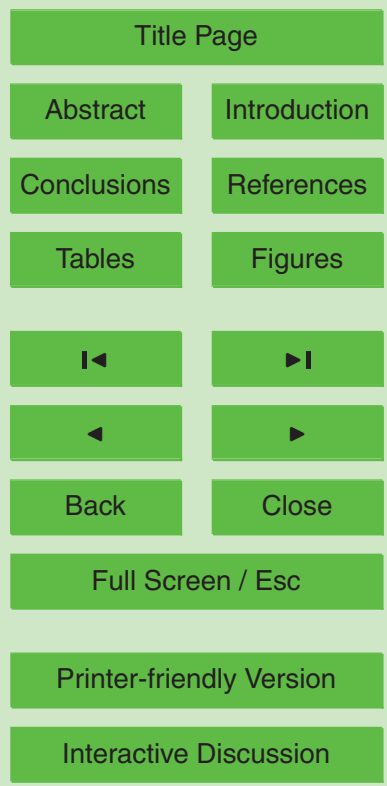


relation structure and (iv) the local inhomogeneities due to orographic effects need to be reproduced in the downscaled GCM field, and the method should be conservative in the sense that $(v)$ the original areal precipitation volume should be preserved. Other statistical properties of the stocastic precipitation process, such as the variance, the 5 frequency distribution and the correlation in time, were verified a posteriori after the downscaling on an empirical basis.

For the temperature data a simple downscaling was applied instead by correcting the mean daily temperature averaged on the GCM grid cell with an altitudinal bias. Because minimum and maximum daily temperature were required for the hydrological 10 model, the observed min-max ranges at the local and monthly scale were applied to correct the mean daily temperature. Both downscaling procedure are described in detail in the following.

\subsection{Precipitation downscaling}

In this work a two step downscaling scheme was defined. The first step bridges the gap 15 between the spatial average of the precipitation at the GCM grid scale and at the basin scale. The second one, instead, provides local precipitation patterns for the raingauge stations inside the basin. The patterns are either extracted from a dataset, based on the precipitation events measured in the period 1979-1999, or they are defined by a deterministic orographic correction. The first approach to the pattern extraction was applied to the Oglio River basin. This method accounts for the wide altitudinal range of the catchment area and for the presence of an orographic optimum inside it. The method uses the pattern variability of the precipitation events which can affect the catchment. (An orographic optimum is a range of altitude characterised by a pluviometric maximum, due to moisture condensation driven by an orographic lift of the air masses and

convection.) The Lys river basin, the area of which is smaller, was divided in two parts with precipitation following the respective altitude.

Therefore two different datasets, fully described by Ranzi et al. (2005), were used in the downscaling processes. For the first step a regional and coarse dataset of rain-

\section{HESSD}

6, 3089-3141, 2009

\section{Climate change and runoff regimes in the southern Alps}

S. Barontini et al.

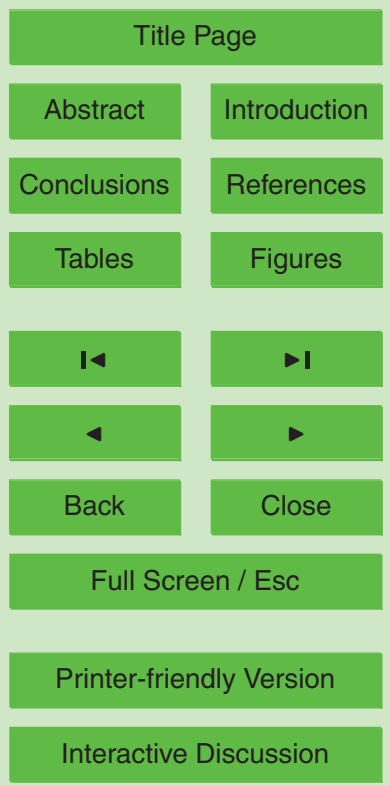

Interactive Discussion 
gauges observations was selected. The gauges are uniformly spread over the Italian Alps and the Po river valley and provide daily rainfall measurements, starting from 1 January 1970, and lasting to 31 December 1994. The central and eastern Alps were chosen as a reference regional scale with $\ell_{\mathrm{REG}} \sim 252 \mathrm{~km}$ determined on the basis of the 5 minimum rectangular area including all the raingauges. Within this region, two other smaller-scale regions were selected, the central Alps (33 stations, $\ell_{\mathrm{CA}} \sim 135 \mathrm{~km}$ ) and the Oglio river basin inside the latter $\left(6\right.$ stations, $\left.\ell_{b} \sim 27 \mathrm{~km}\right)$. The reference regional scale $\ell_{\mathrm{REG}}$ is close to the GCM scale $\ell_{\mathrm{GCM}} \sim 217 \mathrm{~km}$. A local and denser dataset of raingauge measurements was then chosen for the second step of the downscaling pro10 cedure. It consists of 16 stations in the Oglio river basin and 2 stations in the Lys river basin. Data covers the period from 1 January 1979, to 31 December 2000, and from 1 January 1979, to 31 May 2004, for the stations in the Oglio and the Lys catchment, respectively. The data were then corrected in order to account for the measurement error due to the underestimation of the snowfall by raingauges and the variability of the raingage network density vs. the basin hypsometry, as suggested by Ranzi et al. (1999). A precipitation-correction factor of 1.5 was assumed for the snow fraction of the precipitation, accounting for a linear variation of the snow fraction from 1.0 to 0.0 as the daily mean temperature rises from $0^{\circ} \mathrm{C}$ up to $2^{\circ} \mathrm{C}$.

In order to present the downscaling scheme, let us, first of all, define $\lambda=\ell_{1} / \ell_{2}$ as a generic scaling ratio between two characteristic scale lengths $\ell_{1}$ and $\ell_{2}<\ell_{1}$. The first step consists in a stochastic downscaling of the daily GCM spatial-average precipitation $P_{\ell_{\mathrm{GCM}}}^{\mathrm{GCM}}(t)$ at the GCM grid scale $\ell_{\mathrm{GCM}}$, to a realisation of the daily average precipitation $P_{\ell_{b}}^{\mathrm{GCM}}(t, x)$ at a scale $\ell_{b}$, close to the basin scale. In our notation $P_{\ell_{\mathrm{GCM}}}^{\mathrm{GCM}}(t)$, as well as $P_{\ell_{\mathrm{REG}}}^{\mathrm{REG}}(t)$ with the same symbol but for the oberved data at the regional scale, is 25 considered a stochastic process with time parameter $t$, and $P_{\ell}^{\mathrm{GCM}}(t, x)$ a stochastic process, averaged at scale $\ell$, with time $(t)$ and space $(x)$ parameters. Moreover, in the following the operator $\langle\cdot\rangle$ represents the spatial average and the operator $E[\cdot]$ the time average.

\section{HESSD}

$6,3089-3141,2009$

\section{Climate change and runoff regimes in the southern Alps}

S. Barontini et al.

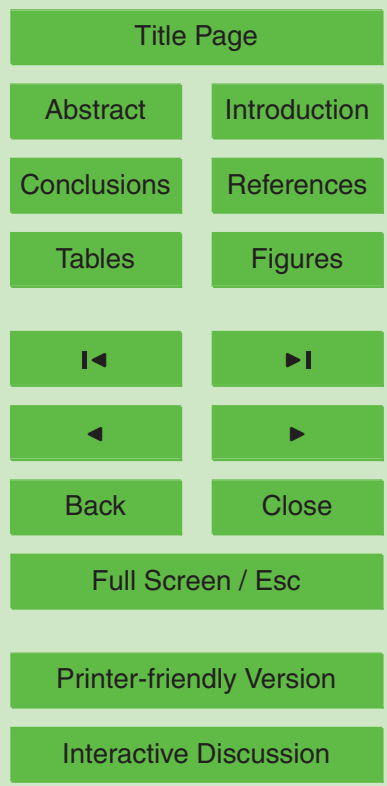


The realisation $P_{\ell}^{\mathrm{GCM}}(t, x)$ should first of all be consistent with the observed annual precipitation over the spatial domain at all the $\ell$-scales of the hystorical data. This property is considered to be achieved if the time-average $\mathrm{E}\left[P_{\ell}(t, x)\right]$ of the observed precipitation $P_{\ell}(t, x)$ at the scale $\ell$, is the same of the respective downscaled GCM 5 process, i.e.

$\mathrm{E}\left[P_{\ell}(t, x)\right]=\mathrm{E}\left[P_{\ell}^{\mathrm{GCM}}(t, x)\right]$.

A realisation for $P_{\ell}^{\mathrm{GCM}}(t, x)$, with the above properties, can be obtained with the following downscaling:

$P_{\ell}^{\mathrm{GCM}}(t, x)=\alpha_{c} \alpha_{r}(x) \alpha_{p}(t, x) P^{\mathrm{GCM}}(t)$.

10 The coefficients introduced in Eq. (2) have the following meaning:

- $\alpha_{c}$ is a deterministic climatic coefficient accounting for a bias in the annual mean of the GCM control simulation vs. the experimental data at the regional scale $\ell_{\mathrm{REG}}$. Defining the spatial average at the regional scale $P_{\ell_{\mathrm{REG}}}^{\mathrm{REG}}(t)=\langle P(t, x)\rangle_{\ell_{\mathrm{REG}}}$ then $\alpha_{c}$ is defined by:

$$
\alpha_{c}=\frac{\mathrm{E}\left[P_{\ell_{\mathrm{REG}}^{\mathrm{REG}}}^{\mathrm{R}}(t)\right]}{\mathrm{E}\left[P_{\left.\ell_{\mathrm{GCM}}^{\mathrm{GCM}}(t)\right]}\right.}
$$

$-\alpha_{r}(x)$ is a deterministic spatial orographic weight accounting for the bias of the mean observed precipitation $\mathrm{E}\left[P_{\ell_{b}}(t, x)\right]$, at the basin scale $\ell_{b}$, with respect to the mean observed precipitation $\mathrm{E}\left[P_{\ell_{\mathrm{REG}}}^{\mathrm{REG}}(t)\right]$ at the regional $\ell_{\mathrm{REG}}$-scale. It is therefore given by:

$$
\alpha_{r}(x)=\frac{\mathrm{E}\left[P_{\ell_{b}}(t, x)\right]}{\mathrm{E}\left[P_{\ell_{\mathrm{REG}}^{\mathrm{REG}}}^{\mathrm{REG}}(t)\right]},
$$

\section{HESSD}

6, 3089-3141, 2009

Climate change and runoff regimes in the southern Alps

S. Barontini et al.

Title Page

Abstract Introduction

Conclusions References

Tables Figures

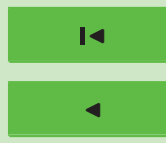

Back

Close

Full Screen / Esc

Printer-friendly Version

Interactive Discussion 
and, by the linearity of expectations, one has:

$$
\left\langle\alpha_{r}(x)\right\rangle_{\ell_{\mathrm{REG}}}=1
$$

- $\alpha_{p}(x, t)$ is a stochastic multiplicative coefficient, accounting for the probability that a rainy day at a larger scale is still rainy at a subscale. The stochastic process $\alpha_{p}(x, t)$ is assumed to be homogeneous in space and time. To define $\alpha_{p}(x, t)$ we will apply the concepts inherent in the $\beta$-model originally proposed by Novikov and Stewart (1964) and later developed by Frisch et al. (1978) and Benzi et al. (1984) to explain some statistics of intermittent fully developed turbulence. Our choice was justified because of the simplicity of the model and because we were interested mainly in the representation of rainfall and runoff regimes rather than on the extremes. One starts from a field characterised by a scale length $\ell_{1}$ and unitary average energy over the whole area. The hypothesis that in the field at a smaller scale the energy splits in active and inactive cells, i.e. without energy, was introduced. The model then suggests possible realisations of the downscaled field of energy, with scaling length $\ell<\ell_{1}$, in order to preserve the total energy of the upper scale field. With a conceptual similarity with the downscaling of energy in turbulence, considering that the spatial pattern of precipitation is largely influenced by the turbulent structure of the atmosphere and by the dissipation of energy in localised convective cells, such mono-fractal and, later, multi-fractal models (e.g. Lovejoy and Schertzer, 1990; Gupta and Waymire, 1993; Deidda, 2000) have been used in order to describe and reconstruct the properties of precipitation fields at different scales as well. The precipitation should then be substituted to the energy in the model and active cells are those where it is raining, while inactive cells represent dry areas.

The multiplicative coefficients $\alpha_{p}(t, x)$ concentrate the spatial average precipitation $P_{\ell_{1}}(t, x)$, given at the reference scale, in wet areas with higher precipitation leaving a wet fraction $\beta$ of the total area $\ell_{1}^{2}$.

\section{Climate change and runoff regimes in the southern Alps}

S. Barontini et al.

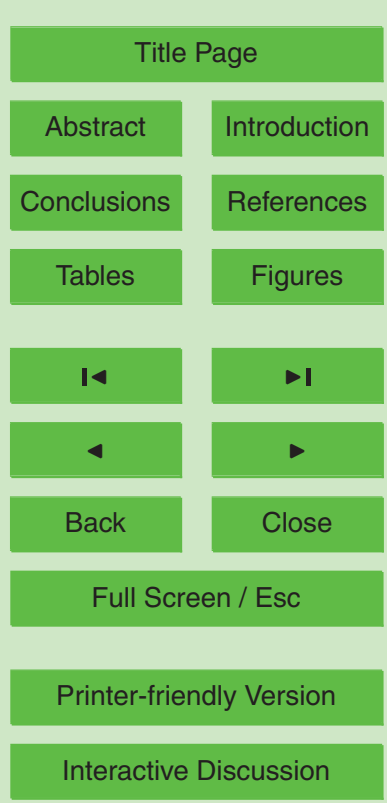

Interactive Discussion 
Let us define $\beta$ the "persistency" of the precipitation process across two spatial scales, i.e. the probability that at a given time a sub-cell at the scale $\ell_{2}<\ell_{1}$ is still rainy when precipitation occurs at the larger scale $\ell_{1}$. By generating independent and identically distributed random values $b$ with a uniform distribution in $[0,1]$, then the random weights $\alpha_{p}$ will have a binomial distribution with the following values:

$\alpha_{p}(x, t)=\left\{\begin{array}{ll}0 & \text { if } b>\beta=\lambda^{-c} \\ \lambda^{c} & \text { if } b \leq \beta=\lambda^{-c}\end{array}\right.$.

In Eq (6) $c>0$ is the mono-fractal codimension of the precipitation field, being $c=2-D$, with $D$ the mono-fractal dimension of the 2-dimensional field. The procedure to estimate the parameter of Eq. (6) will be explained in Sect. 3.1.1. Here it is only recalled that, by construction, $\alpha_{p}(x, t)$ is a homogeneous and stationary stochastic process with unit mean:

$$
\left\langle\alpha_{p}(x, t)\right\rangle_{\ell}=1
$$

$$
\mathrm{E}\left[\alpha_{p}(x, t)\right]=1
$$

In order to apply it to downscale the GCM-simulated precipitation to the $\ell$-scale of interest, a scaling ratio

$\lambda=\frac{\ell_{\mathrm{GCM}}^{*}}{\ell}$

should be applied. In Eq. (9) $\ell_{\mathrm{GCM}}^{*}$ is an equivalent virtual GCM scale, for which the statistics of dry days are coherent with those of the experimental data at a regional scale. In our work we found, for PCM precipitation data, $\ell_{\mathrm{GCM}}^{*}=1737.3 \mathrm{~km}$ (for further details, see Sect. 3.1.1).

HESSD

6, 3089-3141, 2009

Climate change and runoff regimes in the southern Alps

S. Barontini et al.

Title Page

Abstract

Introduction

Conclusions

References

Tables

Figures

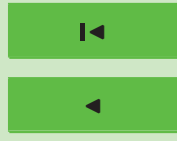

$\rightarrow 1$

Back

Close

Full Screen / Esc

Printer-friendly Version

Interactive Discussion 
Taking the expectation of the downscaled precipitation expressed by Eq. (2), by means of the definitions $(3,4,6)$ and of the relationships $(5,7,8)$, and accounting for the statistical independency of $P^{\mathrm{GCM}}$ and $\alpha_{p}$, one can verify that the mean annual precipitation is conserved throughout all the averaging scales $\ell$. The procedure de5 scribed up to now allows to downscale historical GCM data down to the $\ell$-scale of interest. It is applied also to future GCM scenarios assuming stationarity in time of the $\alpha_{p}$ process.

In Figure 3 the cumulative frequency of exeedance is represented for the spatial average at the basin scale of the measured and for the PCM-simulated daily precipi10 tation. As discussed above, it is shown that the original PCM dataset is characterised by higher probability of rainy days than the observed ones, and lower cumulative frequency of exeedance at higher values of daily precipitation. Moreover it can be observed that for the plotted grid-point, which corresponds to the nearest one to the Oglio river basin area, no significant change of the statistics of daily precipitation, neither in 15 the dry days nor in the extremes, is projected for the future scenarios. Otherwise both the downscaled PCM-simulated series for the historical period and the PCM-projected series for the future scenarios are in good agreement with the fraction of dry days, corresponding to the atom in the origin of the probability distribution, and the cumulative frequency of exeedance of the measured data. As a further a posteriori verification of the effectiveness of the multiplicative cascade model, the variance of the downscaled GCM data for the control period was $49.5 \mathrm{~mm}^{2}$ vs. $47.4 \mathrm{~mm}^{2}$ of the observed data.

A further step of the disaggregation scheme consists in an analogue downscaling of the spatial average of the daily precipitation $P_{\ell}^{\mathrm{GCM}}(t, x)$ to the daily precipitation at the $i$-th raingauge station $P_{i}^{\mathrm{GCM}}\left(t, x_{i}\right)$. Focusing on the basin-centered, coarser, 25 historical dataset, for each $k$-th rainy day the precipitation pattern is defined by way of the normalised precipitation at each $i$-th raingauge station $\left(p_{k, i}\right)$, i.e.:

$p_{k, i}=\frac{P_{k, i}}{P_{k, e}}$
HESSD

6, 3089-3141, 2009

\section{Climate change and runoff regimes in the southern Alps}

S. Barontini et al.

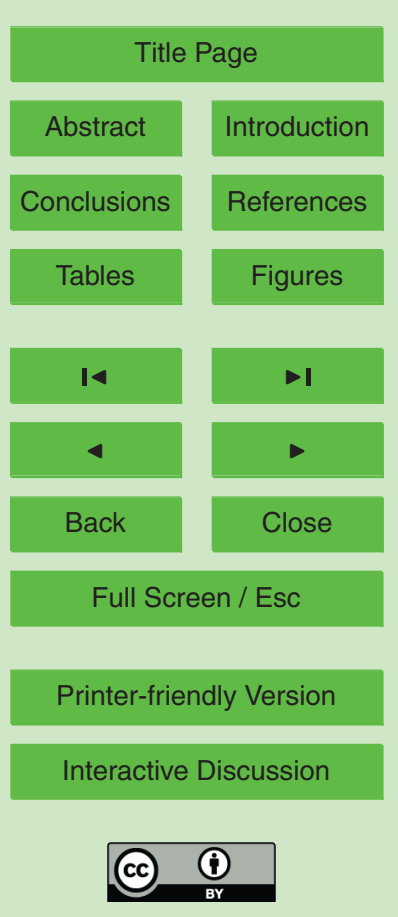


in which $P_{k, i}$ is the daily precipitation measured at the $i$-th raingauge station and $P_{k, \ell}$ is, as before, the spatial average precipitation at the basin scale $\ell$. By applying the classical Thyssen-Voronoi scheme to determine the average spatial precipitation in a basin, one has, by definition:

${ }_{5} \quad P_{k, \ell}=\sum_{i} w_{i} P_{k, i}$,

where $w_{i}$ are the Thyssen-Voronoi weights of each raingauge. Accounting for Eq. (10), one therefore obtains:

$\sum_{i} w_{i} p_{k, i}=1$

Equation (12) verifies that the superimposition of a pattern set $\left(p_{k, i}\right)$, based on the his10 torical $k$-th rainy day, on the average spatial precipitation $P_{j}^{\mathrm{GCM}}$, will preserve both the spatial average and the spatial correlation structure of precipitation. This completes the downscaling process of the precipitation. Measured and PCM-simulated precipitation regimes, both original and downscaled, are represented in Table 4, jointly with the simulated runoff.

\subsubsection{The stochastic process $\alpha_{p}$ for downscaling the precipitation data}

It was observed that the fraction of wet days $n_{w}=\frac{N_{w}}{N_{\text {tot }}}$, being $N_{w}$ the number of days with positive precipitation over the total number of days $N_{\text {tot }}$, if averaged at the $\ell$-scale, increases with the length scale with a power law as shown in Fig. 4:

$n_{w, \ell_{1}}=n_{w, e_{2}} \lambda^{c}$,

HESSD

$6,3089-3141,2009$

Climate change and runoff regimes in the southern Alps

S. Barontini et al.

Title Page

Abstract

Introduction

Conclusions

References

Tables

Figures

14

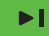

4

Back

Close

Full Screen / Esc

Printer-friendly Version

Interactive Discussion

$\lambda=\frac{\ell_{1}}{\ell_{2}}$. 
From the slope $c$ of this power law on a logarithmic chart the mono-fractal codimension of the precipitation field was estimated as $c=0.195$. Because of our hypothesis of stationarity and homogeneity, statistics of rainy areas can be derived from the time series of precipitation averaged at different scales centered on the target basin.

$5 \quad$ As a consequence of Eq. (6), in view of mass conservation $P_{\ell_{1}}$, each rainy cell at the $\ell_{2}$-scale will receive a precipitation intensity $P_{\ell_{2}}$ given by the enhancement by a factor $\lambda^{c}$ of the upper scale precipitation intensity $P_{\ell_{1}}$ :

$P_{\ell_{2}}=P_{\ell_{1}} \lambda^{c}$.

It was observed that the estimated probability of wet days for GCM simulation of the 10 control period, $n_{w, \ell_{\mathrm{GCM}}}$, was significantly higher than the corresponding observations at the same scale. Therefore, having already estimated the value of $c$, by means of Eq. (13) it was possible to determine the virtual GCM scale $\ell_{\mathrm{GCM}}^{*}$, we introduced before, and characterised by a probability of wet days in agreement with the historical data. The corresponding point is represented by a red dot in Fig. 4.

\subsection{Temperature downscaling}

In order to downscale the mean daily ( $j$-th) temperature given at the reference GCM cell, $T_{j}^{G C M}$, the experimental annual climatic mean $T_{y}$, at the basin scale, was considered as a reference value to be achieved in the historical scenario. Moreover the experimental deviation of the monthly ( $m$-th) mean at each station, $T_{i, m}=\mathrm{E}\left[T_{i, j}\right]_{m}$, from the monthly mean at the basin scale $T_{m}=\left\langle T_{i, m}\right\rangle$ was intended to be respected. These results were achieved by defining the mean daily corrected temperature $T_{i, j}^{\mathrm{GCM}}$, at the $i$-th station and after GCM data in the control run, by means of the following two steps corrections of the GCM daily temperature $T_{j}^{\mathrm{GCM}}$ :

\section{HESSD}

6, 3089-3141, 2009

Climate change and runoff regimes in the southern Alps

S. Barontini et al.

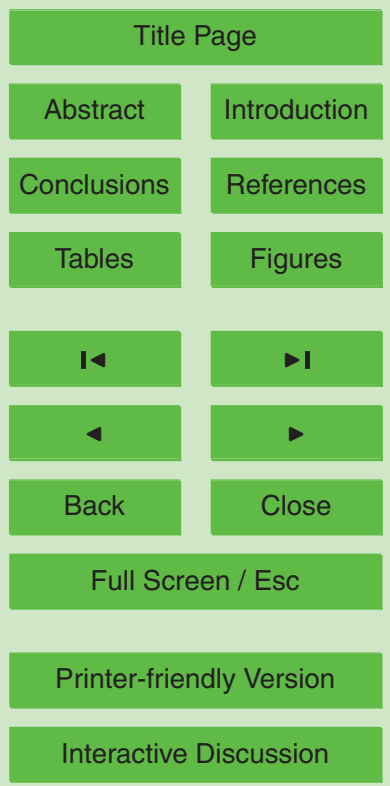


The first bias applied, $\delta T_{i, m}$, is a monthly shift accounting for the difference between $T_{i, m}$ and the monthly mean of all the stations in the river basin, $T_{m}$, and it is therefore defined by:

$\delta T_{i, m}=T_{i, m}-T_{m}$.

5 The second one is a yearly shift, accounting for a modeling bias, i.e. the difference between the climatic mean of all the meteorological stations $T_{y}=\left\langle\mathrm{E}\left[T_{i, j}\right]_{y}\right\rangle$ and the climatic mean of the $\mathrm{GCM}$-data $T_{y}^{\mathrm{GCM}}=\mathrm{E}\left[T_{j}^{\mathrm{GCM}}\right]_{y}$ :

$\delta T_{y}^{\mathrm{GCM}}=T_{y}-T_{y}^{\mathrm{GCM}}$.

By averaging on the annual scale the GCM-control run temperature at a station $i$ and 10 by means of Eqs. $(17,18)$, one obtains that:

$T_{i, y}^{\mathrm{GCM}}=T_{i, y}$.

This means that the mean annual value of the simulated temperature is the same as the observed one for each station. As a consequence, also at the basin scale, the annual mean temperature after GCM-data correction is the same as the experimental one:

$T_{y}^{\mathrm{GCM}}=\left\langle T_{i, y}^{\mathrm{GCM}}\right\rangle=T_{y}$.

The monthly deviation $\delta T_{i, m}^{\mathrm{GCM}}$ for the downscaled data, defined as

$\delta T_{i, m}^{\mathrm{GCM}}=\mathrm{E}\left[T_{i, j}^{\mathrm{GCM}}\right]_{m}-\left\langle\mathrm{E}\left[T_{i, j}^{\mathrm{GCM}}\right]_{m}\right\rangle$,

HESSD

6, 3089-3141, 2009

Climate change and runoff regimes in the southern Alps

S. Barontini et al.

can also be determined from Eq. (16) by applying the expected value operator $\mathrm{E}[\cdot]_{m}$ 20 and then the spatial averaging operator $\langle\cdot\rangle$, keeping into account of Eqs. $(17,18)$. One gets:

$\delta T_{i, m}^{\mathrm{GCM}}=T_{i, m}-T_{m}=\delta T_{i, m}$,

Title Page

Abstract

Introduction

Conclusions

References

Tables

Figures

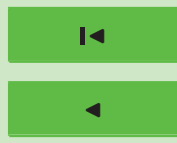

$\rightarrow 1$

Back

Close

Full Screen / Esc

Printer-friendly Version

Interactive Discussion 
i.e., the mean experimental monthly deviation is respected for the downscaled data. Finally, being the spatial averaged monthly temperature of the corrected GCM:

HESSD

$\left\langle\mathrm{E}\left[T_{i, j}^{\mathrm{GCM}}\right]_{m}\right\rangle=T_{m}^{\mathrm{GCM}}+\delta T_{y}^{\mathrm{GCM}}$,

accounting for Eq. (18), one gets:

$5\left\langle\mathrm{E}\left[T_{i, j}^{\mathrm{GCM}}\right]_{m}\right\rangle-T_{y}=T_{m}^{\mathrm{GCM}}-T_{y}^{\mathrm{GCM}}$.

The latter means that the annual regime of the GCM temperature series is maintained, on average, at the basin scale. Measured and PCM-simulated temperature regimes are represented in Table 2.

\section{Hydrological simulations}

\subsection{Simulation hypotheses}

At the hydrological mesoscale the atmospherical system and the hydrological system can be considered uncoupled as the hydrological feedback on the atmospherical processes has already been taken into account in the GCM through approximate schemes. Moreover, the amplitude of the time windows chosen for the simulation of the hydrological response to the climate forcing, which are significant from a water resources management point of view, are quite short as compared to the time scales of the climate change. In this study simulations were therefore driven by the concept that the hydrological system could be considered a steady dynamical system during a time window of 20 years, i.e. during the time window of the simulation the effects of the temperature and precipitation trends were assumed to be negligible against those due to the intrinsic variability of the meteorological forcing. As a consequence, for the future scenarios, we described land cover equilibrium states based on the averaged climatic conditions over the time window of the simulation.
6, 3089-3141, 2009

Climate change and runoff regimes in the southern Alps

S. Barontini et al.

Title Page

Abstract

Introduction

Conclusions

References

Tables

Figures

14

$\rightarrow 1$

4

Back

Close

Full Screen / Esc

Printer-friendly Version

Interactive Discussion 


\subsection{Expected response in mid-latitude natural systems to a climate change sce- nario}

Data reported in Sect. 2.3 point out that the trend of the mean annual temperature will probably be more important than the variation in the annual precipitation amount in 5 characterising the effect of climate change scenarios on the hydrological cycle of the investigated basins. As many Authors suggest, an increase of even a few degrees in the mean annual temperature can have significant feedbacks on the mid-latitude natural systems. Relevant effects were in fact observed on the evolution of the self-vegetation (Theurillat and Guisan, 2001; Walther et al., 2002; Pelfini et al., 2004; Caccianiga et al., 2008) and on the snowpack and glacier equilibrium-line altitude (Kuhn, 1981; Braithwaite, 2008). In this work two main natural-systems' feedbacks were taken into account in order to draw future scenarios for the basin land cover: (i) the rise of the tree-line altitude and (ii) a reduction of the glaciated area.

It is a common feeling that a slight climate warming is often accompanied by the rise of the tree-line at the expenses of pasture and grass at the highest altitudes. This process can be accelerated, in the investigated regions, by afforestation and reforestation processes due to the decline of the wood use for fuel and to the abandonment of the high-altitude pastures (FAO, 2007). In the Mella river basin, a lefthand tributary of the Oglio river in its lower course, Ranzi et al. (2002) observed a significant afforestation and reforestation process in the mountains, jointly with an increase of the urbanised area in the valley. In view of a long-time hydrological simulation, it is important to stress the hydrologically different behaviour of grass- and forest-covered land with regards to the basin evapotranspiration losses. Therefore, according to Galloway (1988), a rise of the tree-line of $100 \mathrm{~m}$ altitude was assumed, on average, every $1^{\circ} \mathrm{C}$ of mean annual temperature. By a cross comparison of CORINE land cover maps and a digital elevation model of the investigated areas, bare soil and grass-covered soil were reclassed as forest for a belt from 200 to $250 \mathrm{~m}$, over the actual tree-line, for the 2079-2099 scenario.

\section{HESSD}

6, 3089-3141, 2009

\section{Climate change and runoff regimes in the southern Alps}

S. Barontini et al.

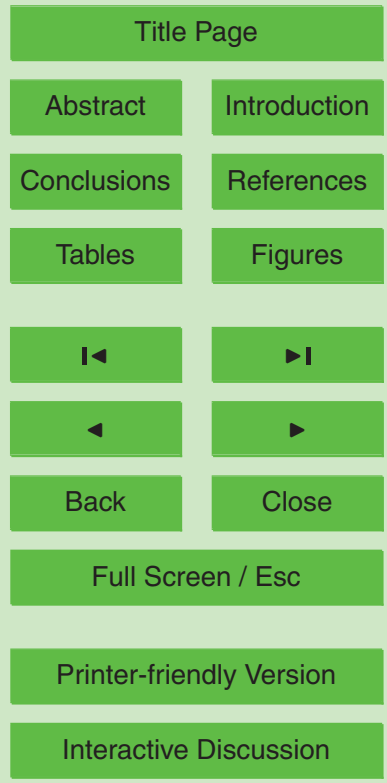

Interactive Discussion 
The rise of the glacier line of equilibrium, and the consequent reduction of the glaciated area, was estimated for the Lys river basin, where the glacier significantly affects the hydrology of the basin. The adopted criterium is based on an energy balance at the equilibrium line of the glacier and it is an application of the concept origi5 nally proposed by Kuhn $(1980,1981)$. The application is based on the hypothesis that the cumulative accumulation $C$ equals the cumulative ablation and allows the determination of the rise of the equilibrium line $\Delta h$. Following Ambach and Kuhn (1985), assuming the variation of the site cloudiness negligible, the variation of the sensible flux $\Delta H_{s}$ and of the net radiation $\Delta R$ can be parametrised with respect to the mean 10 annual temperature $T_{y}$

$$
\begin{aligned}
& \Delta H_{s}=\alpha \Delta T_{y} \\
& \Delta R=\alpha^{\prime} \Delta T_{y},
\end{aligned}
$$

and the equilibrium line rise $\Delta h$, relative to the future-scenario projected variation of the mean annual temperature $\Delta T_{y}$, can be expressed by the relationship:

${ }_{15} \frac{\Delta h}{\Delta T_{y}}=\frac{\alpha^{\prime}+\alpha}{\frac{L}{\tau} \frac{\partial C}{\partial z}-\left(\alpha^{\prime}+\alpha\right) \frac{\partial T_{y}}{\partial z}}$.

The numerical values used in Eq. (27) are given: $L=0.334 \mathrm{MJ} \mathrm{kg}^{-1}$, latent heat of fusion, $\tau=60 \mathrm{~d}$, duration of the ablation period, $\alpha^{\prime}+\alpha=1.66 \mathrm{MJ}^{\circ} \mathrm{C}^{-1} \mathrm{~m}^{-2} \mathrm{~d}^{-1}$, $\partial C / \partial z=1 \mathrm{~kg} \mathrm{~m}^{-2} \mathrm{~m}^{-1}$ (accumulation gradient) and $\partial T_{y} / \partial z=-0.0065^{\circ} \mathrm{C} \mathrm{m}^{-1}$ (temperature gradient). The Kuhn's concept applies to a comparison of equilibrium states. Then, 20 in order to account for the actual disequilibrium of the glaciers, the rise $\Delta h$ was applied to the lowest glacier line observed on the 1991 topographic maps. For the glaciated area of the Lys river basin a rise of about $240 \mathrm{~m}$ was therefore projected to the second half of the $21 \mathrm{st}$ century, consistent with the order of magnitude of the 200 to $300 \mathrm{~m}$-rise estimated by Beniston (2000) for the end of the century.

\section{HESSD}

6, 3089-3141, 2009

\section{Climate change and runoff regimes in the southern Alps}

S. Barontini et al.

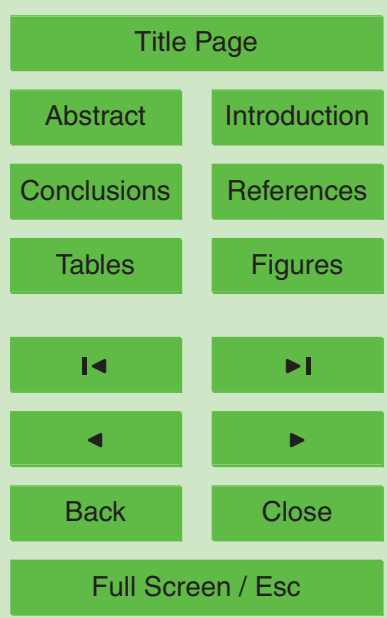

Printer-friendly Version

Interactive Discussion 


\subsection{Hydrological model}

The distributed flood-forecasting model called WATFLOOD (http://www.watflood.ca) Version 9.2.37, compiled on 20 April 2006, was used for our simulations. WATFLOOD is based on the concept of the Group Response Unit (GRU): all hydrologically similar

5 areas within a hydrological model grid are grouped in one unit, then each area belonging to the same unit receives equal meteorological forcing and the group of areas is treated as one modelling unit, no matter the distance among single areas (Kouwen et al., 1993). The structure of the code is suitable for basin time responses ranging from one hour to several weeks.

The model takes into account all the main hydrologic processes: interception, infiltration, evapotranspiration, interflow, baseflow, overland routing and channel routing. The Philip formula (Philip, 1954) is used to estimate the infiltration losses. Overland flow and channel routing are done by a storage routing scheme with time steps chosen to satisfy the Courant criteria everywhere. WATFLOOD was previously applied to the 15 Columbia River in the Rocky Mountains in Canada (Kouwen et al., 2005) and, for the European Alps, to the Toce area (Grossi and Kouwen, 2004) and to the Danube area (Benoit et al., 2004).

For this study an important role is played by the evaluation of the intensity of the evapotranspiration process because changes in the total runoff are basically given by those of the precipitation and evapotranspiration losses. As it is widely accepted that an increase in the mean annual temperature could increase the potential evapotranspiration, and some experimental measurements seem to confirm this effect showing an increase of the observed evapotraspiration (e.g. Genovese et al., 2005; Rosenzweig et al., 2008 and, for the Italian region, Moonen et al., 2002), otherwise some Authors pointed out that an increase in the carbon dioxide concentration in the atmosphere could increase the stomatal resistance to the evapotranspiration, thus reducing the evapotranspiration losses (Gedney et al., 2006) and leading to an increase of the total runoff (Betts et al., 2007). In this work, accounting for a change in the self-vegetation
HESSD

$6,3089-3141,2009$

\section{Climate change and runoff regimes in the southern Alps}

S. Barontini et al.

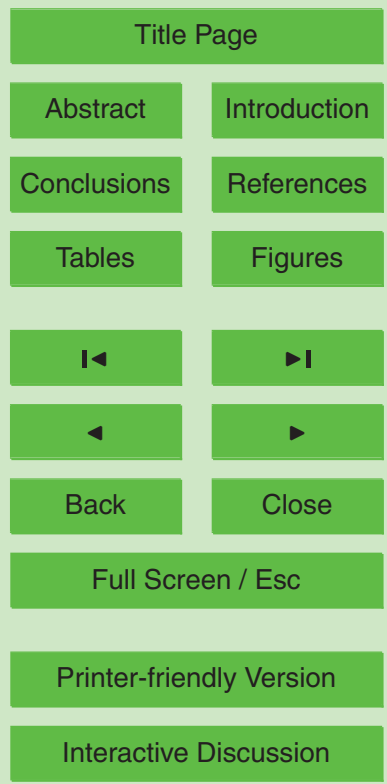


equilibrium and in a consequent species redistribution which is intended to optimize the transpirative capabilities of the plants, we adopted a theoretical framework based on the use of the temperature data to estimate the potential evapotranspiration (PET). In the following a full description of the coding scheme referring to the potential and to 5 the actual evapotranspiration is reported.

PET was evaluated through the Hargreaves equation which can be used when only temperature data are available. The Hargreaves model is empirical in nature and with some recent modifications (Hargreaves and Samani, 1982) takes the form:

$$
\text { PET }=0.0075 R_{a} C_{t} \delta_{t}^{1 / 2} T_{\text {avg }, d}
$$

10 where PET is the potential evapotranspiration rate $\left(\mathrm{mm} \mathrm{d}^{-1}\right), R_{a}$ is the total incoming extraterrestrial solar radiation in the same units as evaporation $\left(\mathrm{mm} \mathrm{d}^{-1}\right), C_{t}$ is a temperature reduction coefficient which is a function of relative humidity $(-), \delta_{t}$ is the difference between the mean monthly maximum and mean monthly minimum temperatures $\left({ }^{\circ} \mathrm{F}\right)$, and $T_{\text {avg, } d}$ is the mean temperature $\left({ }^{\circ} \mathrm{F}\right)$ in the time step. With some 15 empirical relationships it is possibile to estimate incoming solar energy as a function of air temperature, latitude and julian day.

Up to three coefficients have been applied to reduce the calculated PET to the actual evapotranspiration. The first coefficient, the Upper Zone Storage Indicator (UZSI), estimates the evapotranspiration as a function of the soil moisture in the upper soil layer (UZS). Evapotranspiration is assumed to occur at the potential rate if the soil moisture is at a level of saturation (SAT) and is reduced for soil moisture values below the saturation down to zero at the permanent wilting point (PWP) according to equation:

$$
U Z S I=\sqrt{\frac{U Z S-P W P}{S A T-P W P}}
$$

The root of the fraction is used to simulate the increased difficulty with which moisture is extracted by vegetation as the soil dries. The second reduction coefficient (FPET2) applied to the PET to reduce it to the AET is based on the total number of the degree-days

\section{HESSD}

6, 3089-3141, 2009

\section{Climate change and runoff regimes in the southern Alps}

S. Barontini et al.

Title Page

Abstract

Introduction

Conclusions

Tables

References

Figures

14

4

Back

Close 
which is accumulated beginning on 1 January. The third coefficient used to reduce the PET is a function of the vegetation type. For tall vegetation, it has been shown that the evapotranspiration is significantly less than the potential rate (Spittlehouse and Black, 1981; Price, 1987). Typical values of AET from tall vegetation range from 60 (Stagnitti 5 et al., 1989) to $90 \%$ of the PET. Past simulations have successfully used a reduction coefficient of 0.70 applied to the PET rate for the coniferous land classification.

The final reduction in transpiration is a function of the interception. Evaporation of intercepted water is assumed to occur preferentially to soil water transpiration. The sum of the atmospheric resistance and stomatal resistance to water evaporating from 10 stomatal cavities is assumed to be greater than the atmospheric resistance to water evaporating from the surface of the vegetation. In each time step, the transpiration is reduced to zero during periods when interception evaporation (IET) is occurring.

Hydrological and geomorphological characteristics of the two basins were derived from a $1 \mathrm{~km}$ resolution DEM. The maps provided the land use, glacier extension and 15 the surface soil conductivity at saturation.

\section{Results and discussion}

\subsection{Results}

For both the investigated basins, a calibration of the hydrological model was first performed on the basis of the measured data (years 1979-1999). Important pieces of information concerning hydropower management are the mean annual runoff volume, the runoff regimes and the low flow components of the hydrograph. Therefore, by choosing a shorter time window of two years, the calibration focused on the infiltration, storage, evapotranspiration and percolation processes, in order to properly reproduce, at the daily scale, the slow components of the runoff and the baseflow. Key properties were considered the upper soil hydraulic conductivity at saturation, the soil-water retention and the lower zone recession functions. A two-years window (1979-1981), chosen

\section{HESSD}

6, 3089-3141, 2009

\section{Climate change and runoff regimes in the southern Alps}

S. Barontini et al.

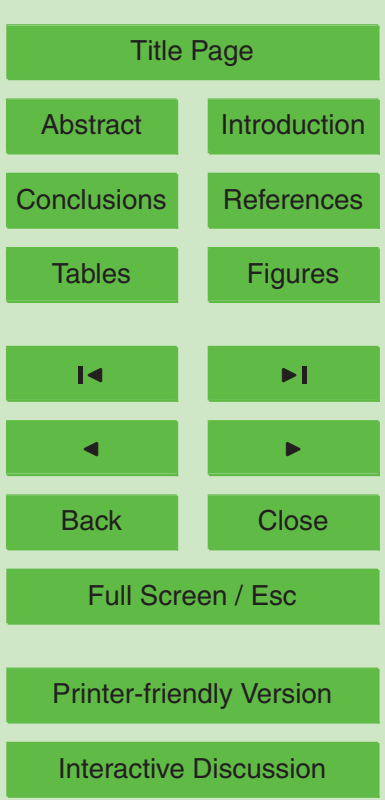

Interactive Discussion 
in order to realistically assume the initial conditions of no snow covering the ground for the two basins, was used for the calibration of the model. Then the long time window 1979-1999 was simulated at the daily scale for a finer tuning of the parameters. As an example, on the basis of the available information and of our field and laboratory ex5 periments in nearby Alpine catchments (Barontini et al., 2005, 2009), an average conductivity value of about $0.2 \mathrm{~mm} \mathrm{~h}^{-1}$ was appropriate for the Lys catchment and slightly lower values were adopted for the Oglio river basin. Such low values account for shallow, non mature soils with a compact underlying bedrock, thus producing a Hortonian runoff even for low rainfall intensity. A snow-melting factor of $0.2 \mathrm{~mm}^{\circ} \mathrm{C}^{-1} \mathrm{~h}^{-1}$ for both 10 basins reasonably represented the observed runoff during the melting period.

In Fig. 5 the results of the control period simulations are represented for the Oglio river basin at Sarnico and compared with the measured data. Similar results were obtained for the Lys river basin. Observed daily runoff at Sarnico, at the outlet of Lake Iseo, were defined by means of the continuity equation, knowing the outflows of the lake and its stage level. Both the calibration simulation with measured data (upper part of the Figure) and the historical simulation driven by PCM-based downscaled data (lower part) are represented. In the central part of the Figure the original PCM-based precipitation data is shown. Low flows in winter are captured by the hydrological model. The $50 \%$ underestimation of the February minimum runoff in the Oglio basin is partially due to regulation by the upstream reservoir and hydropower system which is difficult to be simulated (see Fig. 6). On the contrary, for the natural inflow into Lake Gabiet (see Fig. 7) the discrepancies of the monthly runoff in March is just $6 \%$.

Also spring flows due to the snow-melting are in good agreement, in timing and in volume, for both basins with the observed data.

25 The obtained regimes are represented in Figs. 6 and 7 jointly with the obtained results for the future scenarios. Further details for the Oglio river basin are given in Table 4. As a simulation score the coefficient of correlation of the series of monthly runoff data, forced by observed precipitation in the 1979-1981 calibration period, resulted to be 0.95 and in the 1981-1999 validation period was 0.85 . The coefficient of correlation
HESSD

$6,3089-3141,2009$

\section{Climate change and runoff regimes in the southern Alps}

S. Barontini et al.

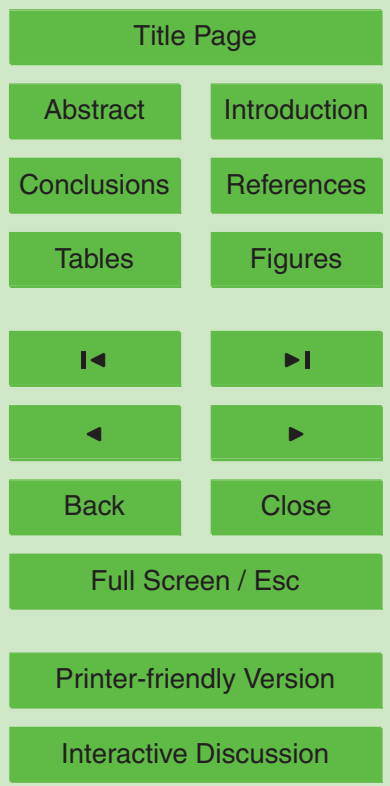


for the obtained monthly regime was 0.92 for the model forced with observed data and 0.88 for the model forced with PCM data.

Focusing on the Oglio river basin, the 1979-1999 simulation forced by measured data is in good agreement with the observed runoff, with an overestimation in the early 5 autumn. Similar results, but with an underestimation in the early autumn, were found for the 1979-1999 simulation forced by downscaled PCM-based data. As it was in fact pointed out in Sect. 2.3 (see Fig. 2 on the left), PCM hystorical regime is already characterised by an underestimation of the autumn precipitations with respect to the alpine sub-litoranean pattern of the investigated area. Anyway a good agreement was ob10 tained between the observed runoff and the PCM-based historical simulation (Table 4), and the latter was therefore considered reliable as a description of the present climate to be compared with the future scenarios.

Similar results were obtained for the Lys river at the Guillemore outlet where the model was calibrated, but here we report only results obtained at the outlet of the 15 small Lake Gabiet sub-basin. The simulation is capable to reproduce the glacial runoff regimes with a good fitting of the winter and early spring minimum, but introduces a delay in the snow- and glacier-melting, underestimating runoff in June and overestimating it in July. The same pattern is shown, even emphasized, by the PCM-based historical simulation. Keeping into account the small size of the basin and the different hydrological behaviour than that of the whole basin where the model was calibrated, the results were still considered satisfactory.

Historical PCM-based simulations were therefore considered reliable as a reference description of the control period climate to be compared with the future scenarios, in order to evaluate the effect of the projected climate on water resources. As a general result we can state that, for the Oglio river basin at Sarnico, a decrease of about $7 \%$ of the annual runoff volume available for the 2050 scenario and of $13 \%$ for the 2090 scenario is projected. Instead for the Lys river basin at Guillemore the annual runoff is foreseen to decrease of about 3\% and 14\% respectively for the 2050 and 2090 scenarios.

HESSD

$6,3089-3141,2009$

\section{Climate change and runoff regimes in the southern Alps}

S. Barontini et al.

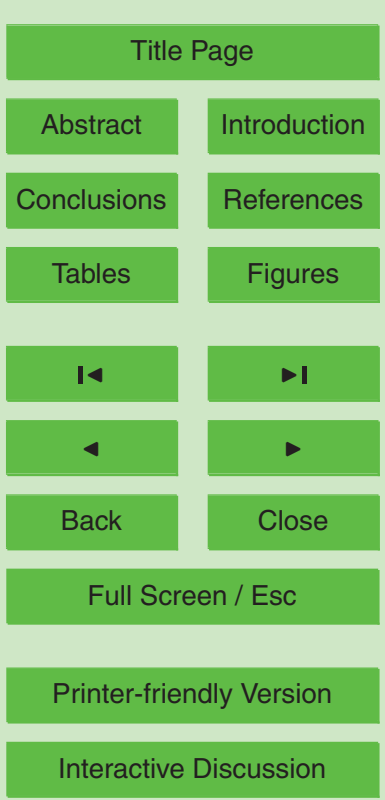




\subsection{Discussion}

Let us focus at first on the Oglio river basin. In the following a comparison within the historical and future PCM scenarios is provided. As the total amount of precipitation as foreseen by PCM simulations will not significantly change in the next century in 5 the target area (see Table 4), the two main features provided by PCM scenarios are changes in the precipitation regime and an increase in the mean annual temperature. With regards to the precipitation regime, Fig. 6 shows that a smoothing of the winter minimum is expected, jointly with a delay and an emphasis of the summer minimum and a sensible delay and smoothing of the autumn peak. As an effect of the increasing mean annual temperature, with almost the same regime as the present one, the winter snowfall will reduce vs. an increase of the winter rainfall.

The effects of such a change on the runoff regime (Fig. 6) will be an increase of the winter runoff, due both to the increase of the precipitation and of the rainfall fraction. Moreover due to the increased temperature, snow-melt will be anticipated and,

15 as a consequence of the reduced snowpack accumulation, it will be reduced. Summer runoff volume is foreseen to significantly reduce and the summer minimum of discharge will be more severe an delayed following precipitation scenarios. Also autumn runoff will be noticeably delayed.

Similar patterns are recognised in the glacial sub-basin of Lake Gabiet within the Lys river basin (Fig. 7). PCM based scenarios for the precipitation are smoother, with respect to the observed one, both for the present and for the future, and the summer minimum of July has already been delayed to September in the present scenario. Autumn and winter runoff is foreseen to increase through the century, partly because of the higher fraction of precipitation in the form of rain, more significantly in the late autumn, with an onset, at the end of the century, of a secondary peak in November due to the freeze delay. With respect to the PCM-based historical simulation, the runoff peak due to snow- and ice-melting in summer, which is in July for 1979-1999, will be spanned over June and July for the 2040-2060 scenario, and will move to June for the

HESSD

6, 3089-3141, 2009

\section{Climate change and runoff regimes in the southern Alps}

S. Barontini et al.

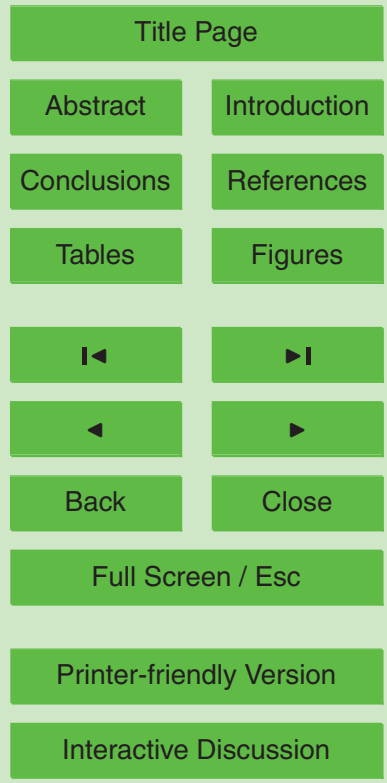

Interactive Discussion 
2079-2099 scenario.

The reduction of the total runoff volume projected for both basins through the century is to be mainly related to the increase of the evapotranspiration losses. Two aspects of our modeling experiment are in fact expected to be responsible for such a 5 behaviour: the increase of the forest-covered area, due to the tree-line rise as described in Sect. 4.2, and the use of a temperature-based model in order to estimate the potential evapotranspiration.

The obtained results, both in the modifications of the regimes' pattern and in the foreseeing of the total annual runoff, are consistent with those of other Authors focusing 10 on the alpine area. As an example Seidel et al. (1998) evaluated the response of the Upper Rhine Basin at Felsberg (eastern Swiss Alps, $3250 \mathrm{~km}^{2}, 560 \div 3614$ m a.s.l., with a runoff regime sensibly characterised by snow accumulation) to two climate change scenarios, an optimistic and a pessimistc one, for the years 2030 and 2100 . The scenarios are characterised by the increase of temperature and of winter precipitation, and by the decrease of summer precipitation. For the pessimistic one, which can be considered coherent with SRES-A2 scenario, a decrease of $11 \%$ in the total annual runoff is foreseen for 2030 and of $13 \%$ for 2100 .

As a consequence of the increasing temperature and evapotranspiration, of the reduction in the snowfall fraction of the precipitation and of the reduction of the basin discharge, Schaefli et al. (2007) projected a strong reduction (36\%) in the median hydropower productivity at the Mauvoisin Dam for the period 2070-2099 with respect to the control period (1961-1990). The basin (169.3 $\mathrm{km}^{2}, 1961$ to $4305 \mathrm{~m}$ a.s.l.) is located in the southern Swiss Alps. The runoff regime, similar to the Lake Gabiet one, is an a-glacier type (see Spreafico et al., 1992) with a runoff peak in summer and very low 25 flows in winter.

One could question about our procedure of applying the same downscaling criteria calibrated on current conditions to future scenarios. As detailed and extensive investigations about daily precipitations regimes in Italy and the southern Alps show, apart from the weak trend of the total annual precipitation reported by Auer et al. (2007) we
HESSD

6, 3089-3141, 2009

\section{Climate change and runoff regimes in the southern Alps}

S. Barontini et al.

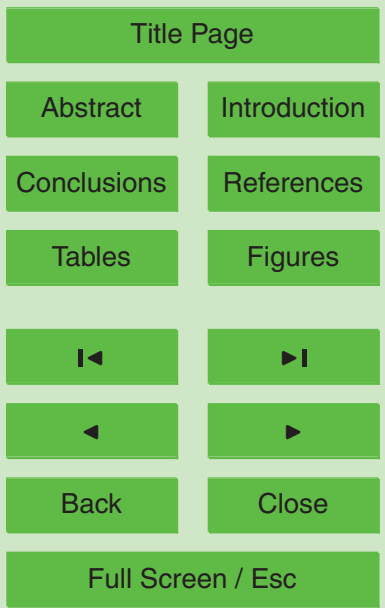

Printer-friendly Version

Interactive Discussion 
already mentioned, no clear trends in the number of dry days and precipitation intensity are observed from the data. For instance Brunetti et al. (2004) show an increase in the number of high intensity events and a decrease in the number of wet days but as their Figs. 4 and 6 show such trends in our investigated areas have a significant level 5 less than $95 \%$ or even $90 \%$. On the basis of these evidences we do not find objective reasons to change the downscaling procedure for future climate.

The significance of the results of our hydrological simulations is affected by the uncertainties of the hydrological models which could be much higher then changes on future climate. Cameron et al. (2000), for instance, explored the uncertainties associ10 ated with the impacts of climate change upon flood frequency for an upland catchment in the UK. They suggest that the tendency for flood frequency increase as a result of climate change may be overridden by hydrological model uncertainties. In our study, based on a deterministic approach we attempt to provide a term of reference for the areas and the hydrological regimes we investigated.

\section{Conclusions}

In this paper the effects of climate change scenarios on the runoff regime of two alpine basins with different size and glaciated area are assessed for this century. We focused the analysis on the precipitation and temperature scenarios produced by the PCM Global Climate Model which proved to be more effective than HADCM and ECHAM in reproducing the observed rainfall and temperature regimes. The A2 scenario was selected for the hydrological simulations. Daily runoff was simulated with the WATFLOOD hydrological model over the 1979-1999 control period and the 2000-2099 period using scenarios provided by PCM. Rainfall and temperature scenarios over two periods centered in the years 2050 and 2090, respectively, and covering the 2040-2060 and the runoff regime.

A two-step downscaling scheme was applied to adapt PCM daily precipitation data

\section{HESSD}

6, 3089-3141, 2009

\section{Climate change and runoff regimes in the southern Alps}

S. Barontini et al.

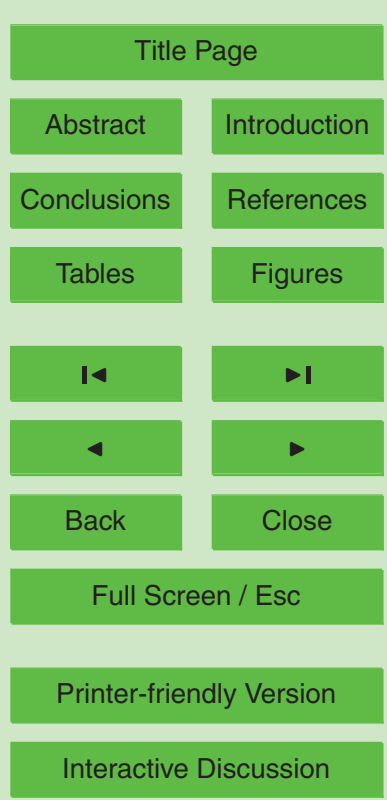

Interactive Discussion 
to the spatial and temporal scale of interest for the investigated basins. Both the intermittency of rainfall in time, i.e. the probability of dry periods, and the spatial correlation structure of observed rainfall were preserved, by keeping the precipitation volume simulated by the PCM model. Simulated and observed cumulative frequency distribution 5 and variance were verified to be in a reasonably good agreement. Correlation in time of downscaled precipitation exhibited instead a more rapid decay than that of measured precipitation. This is a result of the hypothesis of the independency in time in the generation of the downscaling random coefficients. PCM temperatures were corrected to match annual averages and adapted to the basin topography assuming observed 10 monthly lapse rates.

For the 2050 and 2090 climatic projections, land use changes were assumed, on the basis of observations over the last two centuries, since the end of the Little Ice Age, when the treeline altitude increased by $100 \mathrm{~m}$ for every degree of temperature change. In addition for the Lys basin, which is glaciated today for about $8 \%$ of its surface, the 15 future size was adapted to a new equilibrium configuration on the basis of the Kuhn's concept.

According to the A2 scenario the PCM model predicts a mean annual temperature increase of $1.1^{\circ} \mathrm{C}$ for the 2050 -centered period and $2.4^{\circ} \mathrm{C}$ for 2090 , compared to the 1979-1999 average. As a term of comparison for scenario A1B, which is more neutral in terms of anthropogenic factors influencing climate, the same model predicts an increase of $2.0^{\circ} \mathrm{C}$ for 2090 . For a comparison with the other pre-selected GCMs, in the $\mathrm{A} 2$ scenario and regarding the Oglio river basin, an increase of the mean annual temperature ranging from $1.1^{\circ} \mathrm{C}(\mathrm{PCM})$ to $2.7^{\circ} \mathrm{C}(\mathrm{ECHAM})$ is projected for $2040-2060$ with respect to the control simulation, and an increase ranging from $2.4^{\circ} \mathrm{C}(\mathrm{PCM})$ to

$255.5^{\circ} \mathrm{C}$ (ECHAM) is projected for 2079-2099. Lower increases are expected within the framework of the weakly pessimistic $\mathrm{B} 2$ scenario, ranging from $1.0^{\circ} \mathrm{C}(\mathrm{PCM})$ to $2.6^{\circ} \mathrm{C}$ (ECHAM) for $2040-2060$, and from $1.7^{\circ} \mathrm{C}$ (PCM) to $3.8^{\circ} \mathrm{C}$ (ECHAM) projected to 2079 2099.

On the basis of our hypotheses, in view of the application of a PCM-A2 climate

\section{HESSD}

6, 3089-3141, 2009

\section{Climate change and runoff regimes in the southern Alps}

S. Barontini et al.

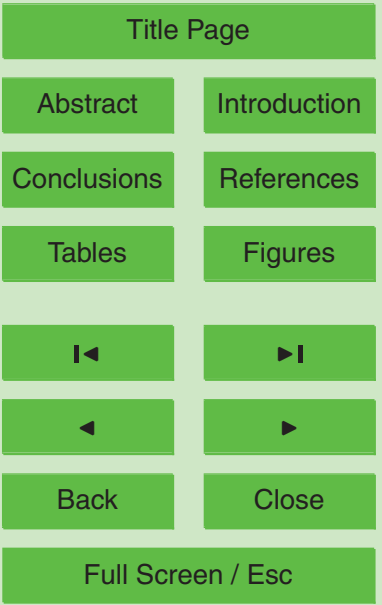

Printer-friendly Version

Interactive Discussion 
change scenario the treeline and the glacier's termini altitude are increased by about 200 to $250 \mathrm{~m}$ and $240 \mathrm{~m}$, respectively, for the end of the century.

Also the projected mean annual precipitation can vary within a wide range depending on the chosen GCM model. Mean annual precipitation for the PCM-A2 scenario 5 should increase of about $3 \%$ and $2 \%$, for the Oglio and Lys basins, respectively, for the period 2050, and it should not significantly vary at the end of this century compared to present conditions. However there is a wide inter-model variability as ECHAM-A2 predicts, for the Oglio river basin, a slight decrease of precipitation, $6 \%$ and $4 \%$ respectively for 2050- and 2090-centered time window; HADCM-A2 is much more pessimistic 10 projecting a decrease of $10 \%$ and $24 \%$ for the mid and the end of this century.

As a consequence of the concurrent effect of temperature and precipitation variation projected by PCM-A2 scenarios, the runoff volumes at the Oglio basin outlet are expected to decrease, because of the higher evapotranspiration losses of about $7 \%$ and $13 \%$, respectively, for the mid and the end of this century. The smaller and more 15 glaciated Lys basin would experience changes in the runoff volume of $3 \%$ and $14 \%$ for the two periods. The runoff regime would experience significant changes especially for this basin, with melt runoff anticipated during the spring and a decrease of snow- and ice-melt runoff in the summer. Because of the uncertainties in both the atmospheric and hydrological simulations and in the socio-economic scenario adopted, these results can provide terms of references for water resources management and engineering design.

Acknowledgements. This work has been financed by the Research Fund for the Italian Electrical System under the Contract Agreement between CESI RICERCA and the Ministry of Economic Development in compliance with the Decree no. 73 18.06.2007. Financial support was 25 granted also by the Italian Ministry of University and Scientific Research grant "Estimation of water resources and drought prediction in mountain basins" and the "CARIPANDA" grant. Authors are grateful to Paola Faggian (CESI RICERCA) for the decoding of global circulation model outputs used in this study. Moreover we acknowledge the modeling groups, the Program for Climate Model Diagnosis and Intercomparison (PCMDI) and the WCRP's Working 30 Group on Coupled Modelling (WGCM) for the WCRP CMIP3 multi-model dataset. Support for

\section{HESSD}

6, 3089-3141, 2009

\section{Climate change and runoff regimes in the southern Alps}

S. Barontini et al.

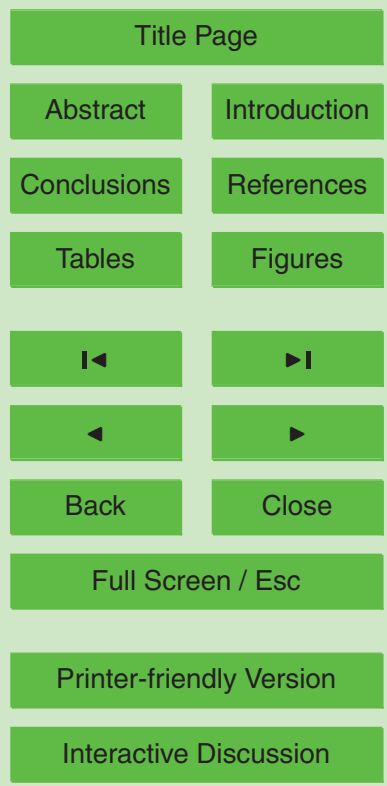


this dataset is provided by the Office of Science, U.S. Department of Energy. The authors thank J. Freer for his useful comments and remarks.

\section{References}

Ambach, W. and Kuhn, M.: Accumulation Gradients in Greenland and Mass Balance Response to Climatic Changes, Zeitschrift fr Gletscherkunde und Glazialgeologie, 21, 311-317, 1985. 3113

Auer, I., Boehm, R., Jurkovic, A., Lipa, W., Orlik, A., Potzmann, R., Schoener, W., Ungersboeck, M., Matulla, C., Briffa, K., Jones, P., Efthymiadis, D., Brunetti, M., Nanni, T., Maugeri, M., Mercalli, L., Mestre, O., Moisselin, J.-M., Begert, M., Mueller-Westermeier, G., Kveton, V., Bochnicek, O., Stastny, P., Lapin, M., Szalai, S., Szentimrey, T., Cegnar, T., Dolinar, M., Gajic-Capka, M., Zaninovic, K., Majstorovic, Z., and Nieplova, E.: HISTALP - historical instrumental climatological surface time series of the Greater Alpine Region, Int. J. Climatol., 27, 17-46, 2007. 3092, 3120

Bacchi, B. and Kottegoda, N.: Identification and calibration of spatial correlation patterns of rainfall, J. Hydrol., 165, 311-348, 1995. 3101

Bandini, A.: Tipi pluviometrici dominanti sulle regioni italiane, Tech. rep., Ministero dei Lavori Pubblici, Roma, Italy, 1931. 3095

Barontini, S., Clerici, A., Ranzi, R., and Bacchi, B.: Saturated Hydraulic Conductivity and Water Retention Relationships for Alpine Mountain Soils, in: Climate and Hydrology of Mountain Areas, edited by: de Jong, C., Collins, D., and Ranzi, R., John Wiley and Sons, Ltd., 101121, 2005. 3117

Barontini, S., Clerici, A., Ranzi, R., and Bacchi, B.: Mapping the upper soil layers saturated hydraulic conductivity in mesoscale alpine basins: a methodology and its applications, in: Hydrology in Mountain Regions: Observations, Processes and Dynamics, HS1003 July 2007 Post-publication, edited by: Marks, D., Red Books, IAHS-AISH Publ. 326, in press, 2009. 3117

Bates, B. C., Kundzewicz, Z. W., Wu, S., and Palutikof, J. P. (eds.): Climate Change and Water. Technical Paper VI of the Intergovernmental Panel on Climate Change, IPCC Secretariat, Geneva, Switzerland, 2008. 3091, 3092, 3093, 3094
HESSD

6, 3089-3141, 2009

\section{Climate change and runoff regimes in the southern Alps}

S. Barontini et al.

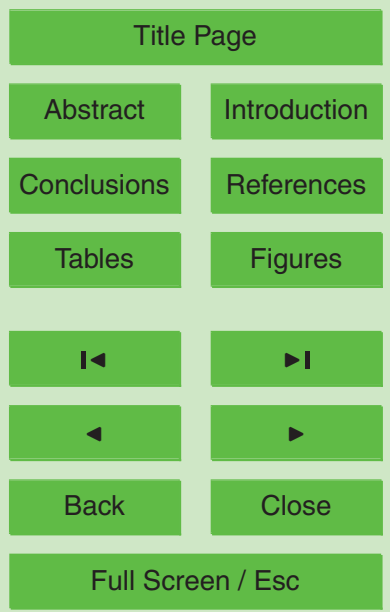

Printer-friendly Version

Interactive Discussion 
Beniston, M.: Environmental change in mountains and uplands, Key Issues in Environmental Change, Arnold Publishers, London, UK, 2000. 3093, 3113

Beniston, M.: Climatic change and its impacts. An overview focusing on Switzerland, vol. 19 of Advances In Global Change Research, Kluver Academic Publishers, Dordrecht, The Nether$5 \quad$ lands, 2004. 3097

Benoit, R., Kouwen, N., Yu, W., Chamberland, S., and Pellerin, P.: Hydrometeorological aspects of real-time ultrafine forecast support during the special observing period of the MAP, Hydrology and Earth Systems Sciences Special issue, 7, 877-889, 2004. 3114

Benzi, R., Paladin, G., Parisi, G., and Vulpiani, A.: On the multifractal nature of fully-developed turbulence and chaotic systems, J. Phys. A-Math. Gen., 17, 3521-3531, 1984. 3105

Betts, R. A., Boucher, O., Collins, M., Cox, P. M., Falloon, P. D., Gedney, N., Hemming, D. L., Huntingford, C., Jones, C. D., Sexton, D. M. H., and Webb, M. J.: Projected increase in continental runoff due to plant responses to increasing carbon dioxide, Nature, 448, 10371041, 2007. 3114

15 Bobba, A. G., Singh, V. P., Jeffries, D. S., and Bengtsson, L.: Application of a watershed runoff model to North-East Pond river, Newfoundland: to study water balance and hydrological characteristics owing to atmospheric change, Hydrol. Process., 11, 1573-1593, 1997. 3093

Braithwaite, R. J.: Temperature and precipitation climate at the equilibrium-line altitude of glaciers expressed by the degree-day factor for melting snow, J. Glaciol., 54, 437-444, 2008. $20 \quad 3112$

Brunetti, M., Maugeri, M., Monti, F., and Nanni, T.: Changes in daily precipitation frequency and distribution in Italy over the last 120 years, J. Geophys. Res.-Atmos., 109, D05102, doi: $\{10.1029 / 2003 J D 004296\}, 2004.3121$

Brunetti, M., Lentini, G., Maugeri, M., Nanni, T., Simolo, C., and Spinoni, J.: 1961-90 highresolution Northern and Central Italy monthly precipitation climatologies, Advances in Science and Research, submitted, 2009. 3101

Burlando, P. and Rosso, R.: Extreme storm rainfall and climatic change, Atmos. Res., 27, 169189, 1991. 3101

Burlando, P. and Rosso, R.: Effects of transient climate change on basin hydrology. 1. Precipitation scenarios for the Arno River, central Italy, Hydrol. Process., 16, 1151-1175, 2002a. 3101

Burlando, P. and Rosso, R.: Effects of transient climate change on basin hydrology. 2. Impacts on runoff variability in the Arno River, central Italy, Hydrol. Process., 16, 1177-1199, 2002b.

HESSD

6, 3089-3141, 2009

\section{Climate change and runoff regimes in the southern Alps}

S. Barontini et al.

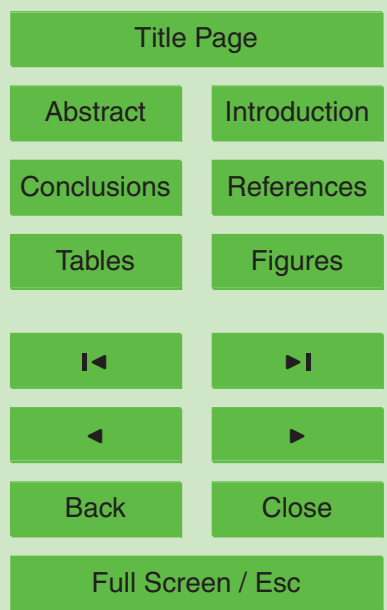

Printer-friendly Version

Interactive Discussion 
Caccianiga, M., Andreis, C., Armiraglio, S., Leonelli, G., Pelfini, M., and Sala, D.: Climate continentality and treeline species distribution in the Alps, Plant Biosyst., 142, 66-78, 2008. 3112

5 Cameron, D., Beven, K., and Naden, P.: Flood frequency estimation by continuous simulation under climate change (with uncertainty), Hydrol. Earth Syst. Sc., 4, 393-405, 2000. 3121

Cowpertwait, P. S. P., O'Connell, P. E., Metcalfe, A. V., and Mawdsley, J. A.: Stochastic point process modelling of rainfall. 2. Regionalisation and disaggregation, J. Hydrol., 175, 47-65, 1996. 3101

10 Deidda, R.: Rainfall downscaling in a space-time multifractal framework, Water Resour. Res., 36, 1779-1794, 2000. 3105

Faggian, P. and Giorgi, F.: Analysis of Future Climate Change Projections for the Italian Alpine Region from the IPCC AR4 Simulations, in: Abstract of WGNE/PCMDI Systematic Errors Workshop, 12-16 February 2007, p. 35, San Francisco, California, USA, 2007. 3092

15 FAO: State of the World's Forests, 2007, Food and Agriculture Organization of the United Nations, Rome, Italy, 2007. 3112

Frisch, U., Sulem, P., and Nelkin, M.: Simple dynamical model of intermittent fully developed turbulence, J. Fluid Mech., 87, 719-736, 1978. 3105

Galloway, R. W.: The potential impact of climate change on Australian ski fields, in: Greenhouse 20 planning for climate change, edited by: Pearman, G. I., CSIRO, Aspendale, Australia, 1988. 3112

Gedney, N., Cox, P. M., Betts, R. A., Boucher, O., Huntingford, C., and Stott, P. A.: Detection of a direct carbon dioxide effect in continental river runoff records, Nature, 439, 835-838, 2006. 3114

Genovese, G., Lazar, C., and Micale, F.: Effects of observed climate fluctuation on wheat flowering as simulated by the European crop growth monitoring system (CGMS), in: Proc. Workshop on Adaptation of Crops and Cropping Systems to Climate Change, 7-8 November 2005, Dalum Landbrugsskole, Odense, Denmark. Nordic Association of Agricultural Scientists, 12 pp., 2005. 3114

30 Gerhard, L. C.: Climate change: Conflict of observational science, theory, and politics, AAPG Bulletin, 88, 1211-1220, 2004. 3091

Gerhard, L. C.: Climate change: Conflict of observational science, theory, and politics: Reply, AAPG Bulletin, 90, 409-412, 2006. 3091

\section{HESSD}

6, 3089-3141, 2009

\section{Climate change and runoff regimes in the southern Alps}

S. Barontini et al.

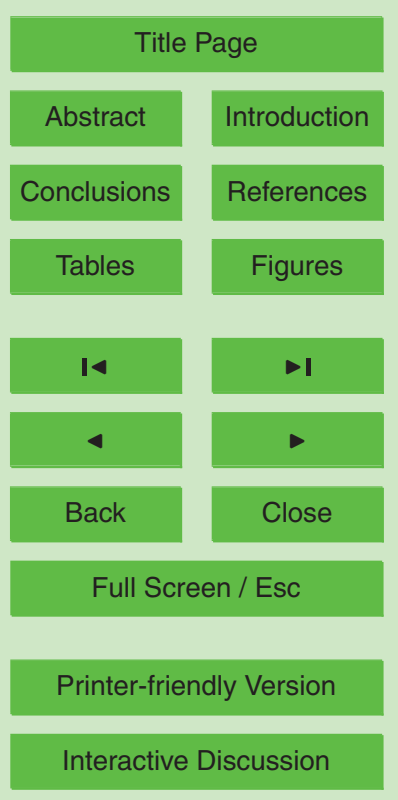


Giorgi, F. and Mearns, L. O.: Approaches to the simulation of regional climate change. A review, Reviews in Geophysics, 29, 191-216, 1991. 3101

Grossi, G. and Kouwen, N.: Intercomparison among hydrologic simulations coupled to meteorological predictions provided by different mesoscale meteorological models, in: Proceedings 5 of XXIX Convegno di Idraulica e Costruzioni Idrauliche, Trento, 7-10 settembre 2004, vol. 2, 265-271, Editoriale Bios, Cosenza, Italy, 2004. 3114

Gupta, V. K. and Waymire, E. C.: A statistical-analysis of mesoscale rainfall as a random cascade, J. Appl. Meteorol., 32, 251-267, 1993. 3105

Hargreaves, G. H. and Samani, Z. A.: Estimating potential evapo-transpiration, J. Irr. Drain. Div ASCE, 108, 225-230, 1982. 3115

Huntley, B.: How plants respond to climate change: migration rates, individualism and the consequence for plant communities, Ann. Bot. London, 67, 15-22, 1991. 3093

IPCC: Radiative Forcing of Climate Change and an Evaluation of the IPCC IS92 Emission Scenarios. Special Report of the Intergovernmental Panel on Climate Change, edited by: Houghton, J. T., Meira Filho, L. G., Bruce Hoesung Lee, J., Callander, B. A., Haites, E., Harris, N., and Maskell, K., Cambridge University Press, Cambridge, United Kingdom and New York, NY, USA, 1994. 3096

IPCC: Emissions Scenarios. Special Report of the Intergovernmental Panel on Climate Change Working Group III, edited by: Nakicenovic, N. and Swart, R., Cambridge University Press,

20 Cambridge, United Kingdom and New York, NY, USA, 2000. 3096

IPCC: Climate Change 2001: Synthesis Report. A Contribution of Working Group I, II, and III to the Third Assessment Report of the Intergovernmental Panel on Climate Change, edited by: Watson, R. T. and the Core Writing Team , Cambridge University Press, Cambridge, United Kingdom and New York, NY, USA, 2001. 3096

IPCC: Climate Change 2007: Synthesis Report. Contribution of Working Groups I, II and III to the Fourth Assessment Report of the Intergovernmental Panel on Climate Change, edited by: Core Writing Team, Pachauri, R. K., and Reisinger, A., IPCC, Geneva, Switzerland, 2007a. 3091, 3092

IPCC: Climate Change 2007: The Physical Science Basis: Working Group I Contribution to the Fourth Assessment Report of the IPCC, edited by: Solomon, S., Qin, D., Manning, M., Chen, Z., Marquis, M., Averyt, K. B., Tignor, M., and Miller, H. L., Cambridge University Press, Cambridge, UK and New York, NY, USA, 2007b. 3091, 3092

Kouwen, N., Soulis, E. D., Pietroniro, A., Donald, J., and Harrington, R. A.: Grouped response

\section{HESSD}

6, 3089-3141, 2009

\section{Climate change and runoff regimes in the southern Alps}

S. Barontini et al.

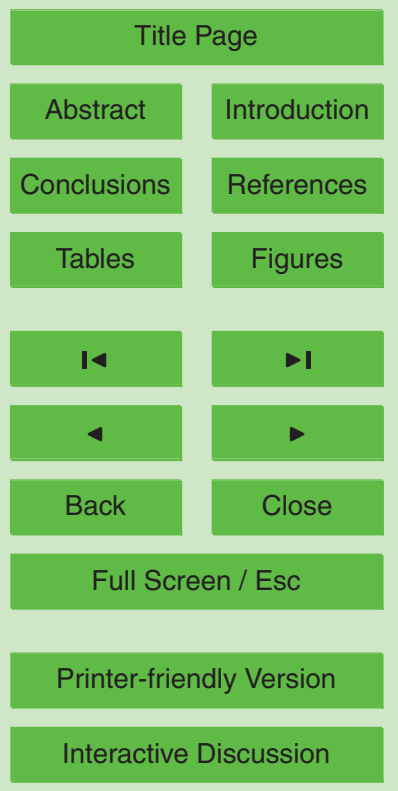


units for distributed hydrologic modeling, J. Water Res. PI. ASCE, 119, 289-305, 1993. 3114

Kouwen, N., Danard, M., Bingeman, A., Lu, W., Seglenieks, F. R., and Soulis, E. D.: Case study: watershed modeling with distributed weather model data, J. Hydrol. Eng., 10, 23-38, 2005. 3114

5 Krysanova, V., Hattermann, F., and Habeck, A.: Expected changes in water resources availability and water quality with respect to climate change in the Elbe River basin (Germany), Nord. Hydrol., 36, 321-333, 2005. 3093

Kuhn, M.: Die Reaktion der Schneegrenze auf Klimaschwunkungen, Zeitschrift fr Gletscherkunde und Glazialgeologie, 16, 241-254, 1980. 3113

10 Kuhn, M.: Climate and glaciers. Sea level, ice and climate changes, in: Proceedings of the Camberra Symposium, December, 1979, IAHS Publications, 131, 3-20, 1981. 3112, 3113

Labat, D., Godderis, Y., Probst, J., and Guyot, J.: Evidence for global runoff increase related to climate warming, Advances in Water Resources, 27, 631-642, 2004. 3093

Legates, D., Lins, H., and McCabe, G.: Comments on "Evidence for global runoff increase 15 related to climate warming" by Labat et al., Advances in Water Resources, 28, 1310-1315, 2005. 3093

Lovejoy, S. and Schertzer, D.: Fractals, raindrops anche resolution dependence of rain measurements, J. Appl. Meteorol., 29, 1167-1170, 1990. 3105

Lovell, B.: Climate change: Conflict of observational science, theory, and politics: Discussion, AAPG Bulletin, 90, 405-407, 2006. 3091

Maurer, E. and Hidalgo, H.: Utility of daily vs. monthly large-scale climate data: an intercomparison of two statistical downscaling methods, Hydrol. Earth Syst. Sc., 12, 551-563, 2008. 3101

Meehl, G. A., Covey, C., Delworth, T., Latif, M., McAvaney, B., Mitchell, J. F. B., Stouffer, R. J., and Taylor, K. E.: The WCRP CMIP3 multimodel dataset - A new era in climate change research, . Am. Meteorol. Soc., 88, 1383-1394, 2007. 3098

Moonen, A., Ercoli, L., Mariotti, M., and Masoni, A.: Climate change in Italy indicated by agrometeorological indices over 122 years, Agr. Forest Meteorol., 111, 13-27, 2002. 3114

Novikov, E. and Stewart, R.: Intermittency of turbulence and spectrum of fluctuations in energydissipation, Nauk. SSSR Geofiz., 3, 408-412, 1964. 3105

Oreskes, N.: Beyond the ivory tower - The scientific consensus on climate change, Science, 306, p. 1686, doi:10.1126/science.1103618, 2004. 3091

Parry, M., Arnell, N., Hulme, M., Nicholls, R., and Livermore, M.: Adapting to the inevitable,

HESSD

6, 3089-3141, 2009

\section{Climate change and runoff regimes in the southern Alps}

S. Barontini et al.

Title Page

Abstract

Introduction

Conclusions

References

Tables

Figures

14

4

Back

Close

Full Screen / Esc

Printer-friendly Version

Interactive Discussion 
Nature, 395, p. 741, doi:10.1038/27316, 1998. 3092

Parry, M., Arnell, N., McMichael, T., Nicholls, R., Martens, P., Kovats, S., Livermore, M., Rosenzweig, C., Iglesias, A., and Fischer, G.: Millions at risk: defining critical climate change threats and targets, Global Environ. Chang., 11, 181-183, 2001. 3092

5 Pelfini, M., Caccianiga, M., Santilli, M., Colombini, C., and Leonelli, G.: II limite degli alberi sulle Alpi Centrali Italiane: andamento spazio-temporale e relazioni con il clima, in: Atti del Convegno in Onore di Ardito Desio, Bormio, 2004. 3112

Pfister, L., Kwadijk, J., Musy, A., Bronstert, A., and Hoffmann, L.: Climate change, land use change and runoff prediction in the Rhine - Meuse basins, River Res. Appl., 20, 229-241, 2004. 3093

Philip, J. R.: An infiltration equation with physical significance, Soil Science, 77, 153-157, 1954. 3114

Price, D.: Some effects of variations in weather and soil water storage on canopy evapotranspiration and net photosynthesis of a young douglas-fir stand, Ph.D. thesis, University of British

Prudhomme, C., Reynard, N., and Crooks, S.: Downscaling of global climate models for flood frequency analysis: where are we now?, Hydrol. Process., 16, 1137-1150, 2002. 3101

Ranzi, R., Grossi, G., and Bacchi, B.: Ten years of monitoring areal snowpack in the Southern Alps using NOAA-AVHRR imagery, ground measurements and hydrological data, Hydrol.

$20 \quad$ Process., 13, 2079-2095, 1999. 3101, 3103

Ranzi, R., Bochicchio, M., and Bacchi, B.: Effects on floods of recent afforestation and urbanisation in the Mella River (Italian Alps), Hydrol. Earth Syst. Sc., 6, 239-253, 2002. 3112

Ranzi, R., Barontini, S., Grossi, G., and Scaroni, P.: Rapporto tecnico sull'influenza dei cambiamenti climatici sulla disponibilitá idrica per la regione campione, Tech. Rep. A5057868 (Annex), CESI, Milan, 2005. 3102

Rosenzweig, C., Karoly, D., Vicarelli, M., Neofotis, P., Wu, Q., Casassa, G., Menzel, A., Root, T. L., Estrella, N., Seguin, B., Tryjanowski, P., Liu, C., Rawlins, S., and Imeson, A.: Attributing physical and biological impacts to anthropogenic climate change, Nature, 453, 353-357, 2008. 3114

30 Schaefli, B., Hingray, B., and Musy, A.: Climate change and hydropower production in the Swiss Alps: quantification of potential impacts and related model uncertainties, Hydrol. Earth Syst. Sc., 11, 1191-1205, 2007. 3093, 3120

Seidel, K., Ehrler, C., and Martinec, J.: Effects of climate change on water resources and runoff
HESSD

6, 3089-3141, 2009

\section{Climate change and runoff regimes in the southern Alps}

S. Barontini et al.

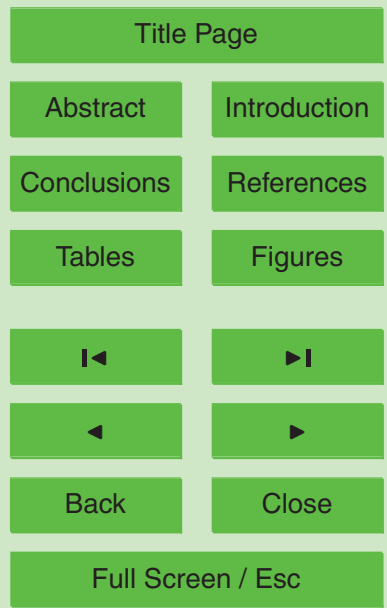

Printer-friendly Version

Interactive Discussion 
in an Alpine basin, Hydrol. Process., 12, 1659-1669, 1998. 3093, 3120

Spittlehouse, D. L. and Black, T. A.: A growing-season water-balance model applied to 2 douglas-fir stands, Water Resour. Res., 17, 1651-1656, 1981. 3116

Spreafico, M., Weingartner, R., and Leibundgut, C.: Atlas hydrologique de la Suisse, Service Hydrologique et Gologique National (SHGN), Bern, Switzerland, 1992. 3120

Stagnitti, F., Parlange, J. Y., and Rose, C. W.: Hydrology of a small wet catchment, Hydrol. Process., 3, 137-150, 1989. 3116

Theurillat, J.-P. and Guisan, A.: Potential impact of climate change on vegetation in the european alps: a review, Climatic Change, 50,77-109, 2001. 3112

UNEP-WGMS: Global Glaciers Changes: facts and figures, UNEP, Nairobi, Kenia, 2008. 3091 Walther, G.-R., Post, E., Convey, P., Menzel, A., Parmesan, C., Beebee, T. J., Fromentin, J.M., Hoegh-Guldberg, O., and Bairlein, F.: Ecological responses to recent climate change, Nature, 416, 389-395, 2002. 3093, 3112

Waymire, E., Gupta, V. K., and Rodriguez-Iturbe, I.: A spectral theory of rainfall intensity at the meso- $\beta$ scale, Water Resour. Res., 20, 1453-1465, 1984. 3101

Wilby, R. L. and Wigley, T. M. L.: Downscaling general circulation model output: a review of methods and limitations, Prog. Phys. Geog., 21, 530-548, 1997. 3101

Wilby, R. L., Conway, D., and Jones, P. D.: Prospects for downscaling seasonal precipitation variability using conditioned weather generator parameters, Hydrol. Process., 16, 1215-

\section{HESSD}

6, 3089-3141, 2009

\section{Climate change and runoff regimes in the southern Alps}

S. Barontini et al.

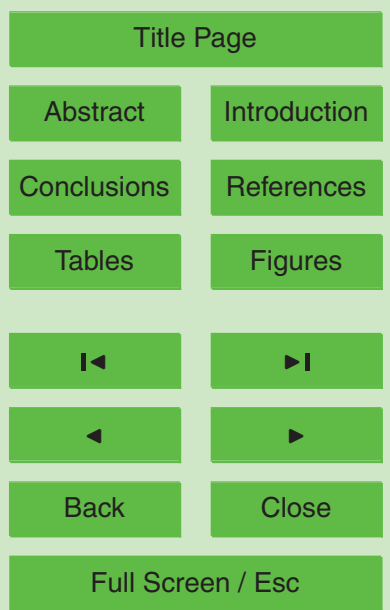

Printer-friendly Version

Interactive Discussion 


\section{HESSD}

6, 3089-3141, 2009

Climate change and runoff regimes in the southern Alps

Table 1. Main physiographical data of the target basins.

\begin{tabular}{lcc}
\hline Basin & Oglio at Sarnico & Lys at Guillemore \\
\hline Name of the area & Valcamonica & Valle d'Aosta \\
Mountain range & Central Italian Alps & northern Italian Alps \\
Area $\left(\mathrm{km}^{2}\right)$ & 1840 & 205 \\
Interlaced area $\left(\mathrm{km}^{2}\right)$ & - & 31 \\
Total area $\left(\mathrm{km}^{2}\right)$ & 1840 & 236 \\
Glaciers $\left(\mathrm{km}^{2}, \%\right)$ & $10.4(0.6 \%)$ & $16.1(8 \%)$ \\
Elevation range $(\mathrm{m}$ a.s.I.) & $187-3539$ & $894-4532$ \\
Average altitude (ma.s.I.) & 1379 & 2251 \\
Main stream channel $(\mathrm{km})$ & 89 & 38 \\
Precipitation $(1979-1999, \mathrm{~mm})$ & 1165 & 1282 \\
Runoff $(1979-1999, \mathrm{~mm})$ & 933 & 907 \\
\hline
\end{tabular}

S. Barontini et al.

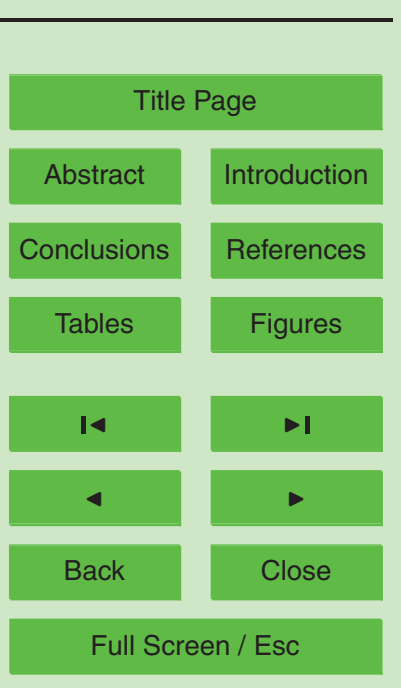

Printer-friendly Version

Interactive Discussion 


\section{HESSD}

6, 3089-3141, 2009

\section{Climate change and runoff regimes in the southern Alps}

Table 2. Measured and PCM-simulated temperature $\left({ }^{\circ} \mathrm{C}\right)$ regimes in the Oglio river basin at Sarnico. Measured data refer to an altitude of $1398 \mathrm{~m}$ a.s.l. close to the average altitude of the basin, while GCM data refer to the height of the local grid cell.

\begin{tabular}{llrrrrrrrrrrrrrr}
\hline Period & & Year & J & F & M & A & M & J & J & A & S & O & N & D \\
\hline $1979-1999$ & Observed & 6.6 & -2.0 & -0.7 & 2.4 & 4.9 & 9.6 & 12.9 & 15.9 & 15.8 & 11.9 & 7.3 & 2.1 & -1.2 \\
$1979-1999$ & PCM & 7.2 & 0.2 & 0.5 & 1.9 & 4.3 & 8.9 & 13.1 & 15.0 & 15.2 & 13.0 & 8.4 & 4.7 & 1.3 \\
$2040-2060$ & PCM-A2 & 8.3 & 0.7 & 1.8 & 2.5 & 6.1 & 9.7 & 13.7 & 16.3 & 16.2 & 13.9 & 10.2 & 5.8 & 2.0 \\
$2079-2099$ & PCM-A2 & 9.6 & 2.5 & 3.0 & 3.7 & 6.2 & 10.9 & 14.5 & 18.1 & 18.2 & 15.7 & 11.7 & 7.5 & 3.6 \\
$2040-2060$ & PCM-B2 & 8.2 & 0.8 & 1.0 & 2.8 & 5.7 & 9.8 & 13.8 & 16.4 & 15.7 & 14.0 & 10.1 & 5.8 & 1.9 \\
$2079-2099$ & PCM-B2 & 8.9 & 1.6 & 2.3 & 3.2 & 6.3 & 11.2 & 14.2 & 17.0 & 17.1 & 14.3 & 10.5 & 6.2 & 3.1 \\
$2079-2099$ & PCM-A1B & 9.2 & 2.0 & 2.4 & 3.5 & 6.3 & 10.3 & 14.0 & 17.8 & 18.4 & 15.4 & 11.1 & 6.5 & 2.9 \\
$1990-1999$ & ECHAM & 8.4 & 1.2 & 0.8 & 2.9 & 5.7 & 10.1 & 15.2 & 18.3 & 17.4 & 13.8 & 9.1 & 3.9 & 1.7 \\
$2040-2060$ & ECHAM-A2 & 11.1 & 3.1 & 3.3 & 5.1 & 8.9 & 12.9 & 17.7 & 22.0 & 21.6 & 17.1 & 11.1 & 6.4 & 3.9 \\
$2079-2099$ & ECHAM-A2 & 13.9 & 4.8 & 5.3 & 7.6 & 11.4 & 15.9 & 21.6 & 26.4 & 25.8 & 20.4 & 13.5 & 8.3 & 5.5 \\
$2040-2060$ & ECHAM-B2 & 10.9 & 2.9 & 3.1 & 5.8 & 9.2 & 12.6 & 17.6 & 21.4 & 21.4 & 16.5 & 10.8 & 6.0 & 3.8 \\
$2079-2099$ & ECHAM-B2 & 12.1 & 3.6 & 4.7 & 6.7 & 9.4 & 13.4 & 19.0 & 22.9 & 23.1 & 18.4 & 12.1 & 7.4 & 4.9 \\
$1979-1999$ & HADCM & 9.0 & -1.0 & 0.0 & 3.7 & 8.1 & 12.6 & 17.3 & 21.0 & 20.2 & 14.7 & 7.9 & 3.1 & -0.1 \\
$2040-2060$ & HADCM-A2 & 11.4 & 0.5 & 1.6 & 5.1 & 9.7 & 14.1 & 19.6 & 24.9 & 24.9 & 18.5 & 11.0 & 5.2 & 2.0 \\
$2079-2099$ & HADCM-A2 & 14.4 & 2.5 & 4.0 & 7.3 & 12.5 & 17.7 & 23.9 & 29.4 & 29.6 & 23.2 & 13.4 & 6.2 & 3.0 \\
2040-2060 & HADCM-B2 & 11.3 & 0.3 & 1.9 & 4.8 & 9.9 & 14.4 & 19.5 & 24.7 & 24.9 & 18.3 & 10.3 & 5.2 & 1.3 \\
2079-2099 & HADCM-B2 & 12.7 & 0.7 & 2.3 & 6.4 & 11.0 & 16.1 & 21.8 & 27.0 & 26.8 & 21.1 & 11.9 & 5.4 & 2.0 \\
\hline
\end{tabular}

S. Barontini et al.

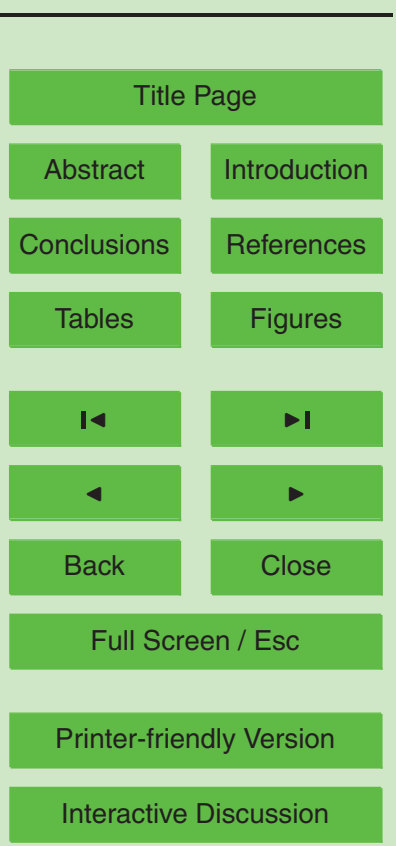




\section{HESSD}

6, 3089-3141, 2009

\section{Climate change and} runoff regimes in the southern Alps

S. Barontini et al.

Table 3. Performance evaluation for the 1979-1999 period of the selected CGMs monthly precipitation regimes (see Sect. 2.3 for details on the abbreviations).

\begin{tabular}{lccc}
\hline GCM & $\begin{array}{c}\text { M-RMSE } \\
\mathrm{mm}\end{array}$ & $\begin{array}{c}\text { V-RMSE } \\
\mathrm{mm}\end{array}$ & $\begin{array}{c}\text { V-MAE } \\
\mathrm{mm}\end{array}$ \\
\hline PCM & 23.33 & 45.25 & 72.41 \\
ECHAM & 22.34 & 46.67 & 90.12 \\
HADCM & 31.49 & 70.86 & 132.00 \\
\hline
\end{tabular}




\section{HESSD}

6, 3089-3141, 2009

\section{Climate change and runoff regimes in the southern Alps}

Table 4. Measured and simulated rainfall and runoff regimes for the Oglio river basin at Sarnico.

\begin{tabular}{|c|c|c|c|c|c|c|c|c|c|c|c|c|c|c|}
\hline Time window & Regime & $\begin{array}{c}\text { Year } \\
\mathrm{mm}\end{array}$ & $\underset{\mathrm{mm}}{\mathrm{J}}$ & $\begin{array}{r}\mathrm{F} \\
\mathrm{mm}\end{array}$ & $\begin{array}{r}\mathrm{M} \\
\mathrm{mm}\end{array}$ & $\begin{array}{r}\mathrm{A} \\
\mathrm{mm}\end{array}$ & $\begin{array}{r}\mathrm{M} \\
\mathrm{mm}\end{array}$ & $\begin{array}{r}\mathrm{J} \\
\mathrm{mm}\end{array}$ & $\begin{array}{r}\mathrm{J} \\
\mathrm{mm}\end{array}$ & $\begin{array}{r}\mathrm{A} \\
\mathrm{mm}\end{array}$ & $\begin{array}{r}\mathrm{S} \\
\mathrm{mm}\end{array}$ & $\begin{array}{r}\mathrm{O} \\
\mathrm{mm}\end{array}$ & $\begin{array}{r}\mathrm{N} \\
\mathrm{mm}\end{array}$ & $\begin{array}{r}\mathrm{D} \\
\mathrm{mm}\end{array}$ \\
\hline 1979-1999 & Observed runoff & 933.1 & 43.3 & 33.5 & 44.7 & 70.6 & 129.0 & 134.0 & 108.8 & 74.7 & 73.2 & 100.7 & 69.1 & 51.5 \\
\hline 1979-1999 & Observed and corrected precipitation & 1165.3 & 68.1 & 38.2 & 64.0 & 94.9 & 126.9 & 129.0 & 114.9 & 117.4 & 113.5 & 136.4 & 85.7 & 76.3 \\
\hline 1979-1999 & imulated runoff after observations & 981.2 & 20.4 & 16.0 & 42.6 & 107.8 & 131.7 & 132.2 & 110.4 & 86.2 & 92.1 & 126.2 & 74.3 & 41.4 \\
\hline 1979-1999 & imulated runoff after PCM & 927.7 & 54.4 & 43.5 & 51.1 & 83.5 & 141.0 & 118.0 & 97.5 & 64.8 & 52.8 & 76.3 & 66.0 & 78.8 \\
\hline 1979-1999 & ${ }^{\mathrm{C}} \mathrm{CM}$ downscaled precipitation & 1198.6 & 85.2 & 57.6 & 78.2 & 102.0 & 138.5 & 110.0 & 138.4 & 89.8 & 89.7 & 105.3 & 92.1 & 111.8 \\
\hline 1979-1999 & in & 59.5 & 62.6 & 50.3 & 67.2 & 97.0 & & 92.5 & 100.9 & & 61.1 & 82.8 & 80.9 & 87.1 \\
\hline $2040-2060$ & after PCM-A2 & 865.3 & 43.0 & 56.1 & 64.2 & 90.8 & 128.7 & 112.6 & 71.9 & 50.7 & 44.6 & 47.6 & 77.5 & 77.6 \\
\hline 2040 & cipitation & 1177.3 & 64.9 & 88.4 & 81.4 & 111.1 & 138.7 & 133.1 & 111.5 & 97.3 & 70.6 & 82.1 & 107.9 & 90.2 \\
\hline $2040-2060$ & $\mathrm{CM}-$ & 992.2 & 55.8 & 64.0 & 66.2 & 99.6 & 113.8 & 106.0 & 91.0 & 80.7 & 59.0 & 78.4 & 95.0 & 82.7 \\
\hline 2079-2099 & PCM-A2 & 810.4 & 62.0 & 64.3 & 82.0 & 105.1 & 126.2 & 86.5 & 63.8 & 32.8 & 22.4 & 29.7 & 65.0 & 70.6 \\
\hline 2079-2099 & $\mathrm{CM}$ & 1129.0 & 75.9 & 84.6 & 110.9 & 119.0 & 140.1 & 110.2 & 98.3 & 70 & 55.3 & 69.2 & 93.4 & 101.3 \\
\hline 2079-2099 & PCM- & 969.8 & 71.4 & 67.2 & 97.5 & 103.9 & 104.2 & 93.0 & 88.5 & 68.9 & 46.5 & 59.6 & 92.3 & 76.9 \\
\hline 1979 & & & 91.1 & 55.2 & & & & 87.3 & 93.6 & & 83.1 & 109.1 & & 66.0 \\
\hline $2040-2060$ & $\mathrm{ECH} A$ & 981.1 & 71.4 & 62.8 & 67.8 & 66.6 & 92.4 & 79.4 & 97.6 & 89.0 & 77.9 & 95.1 & 103.6 & 77.6 \\
\hline 2079-2099 & $\mathrm{ECH}$ & 1005.4 & 82.7 & 57.1 & 55.5 & 60.7 & 70.3 & 86.0 & 103.2 & 96.4 & 70.3 & 111.3 & 106.3 & 105.7 \\
\hline $2040-2060$ & & & 81.8 & 65.9 & & & & 89.0 & 95.7 & 97 & 76.0 & & & 103.0 \\
\hline 2079-2099 & $\mathrm{ECH}$ & 1065.5 & 90.5 & 80.7 & 72.9 & 77.7 & 86.5 & 83.6 & 98.9 & 89.6 & 80.7 & 112.2 & 100.7 & 91.5 \\
\hline 1979-1999 & & & 66.1 & 41.6 & 61.7 & 74.4 & 90.3 & 106.0 & 55.7 & 32 & 53.0 & 70.6 & 71.3 & 61.7 \\
\hline 2040 & & & 49.0 & 42 & & & 88.1 & 77.6 & 31.9 & & 29.7 & 76.3 & 73.1 & 62.3 \\
\hline 2079-2099 & HADCI & 595.6 & 63.6 & 41.7 & 48.7 & 60.1 & 70.4 & 48.4 & 30.6 & 11.4 & 19.9 & 74.1 & 56.7 & 70.0 \\
\hline $2040-2060$ & & & 52.8 & 56.4 & & 61.0 & & 87.1 & 39.9 & & & & 83.4 & 53.0 \\
\hline 2079-2099 & & & 69.1 & 49.3 & & & & 73.4 & 32.6 & & & 73.5 & 73.7 & 84.4 \\
\hline 2040-2060 & PCM-B2 precipitation & 962.2 & 48.3 & 51.6 & 83.6 & 85.0 & 114.0 & 102.6 & 100.7 & 71.4 & 61.0 & 71.4 & 102.0 & 70.7 \\
\hline & & & 58.0 & 62.9 & 81.9 & 96.6 & & 96.7 & 88.6 & 67.6 & 52.1 & 68.3 & 91.0 & 73.1 \\
\hline 2079-2099 & PCM-A1b precipitation & 996.9 & 79.8 & 75.8 & 91.5 & 93.2 & 106.6 & 87.9 & 83.4 & 52.7 & 52.0 & 85.3 & 110.8 & 78.0 \\
\hline
\end{tabular}

S. Barontini et al.

\section{Title Page}

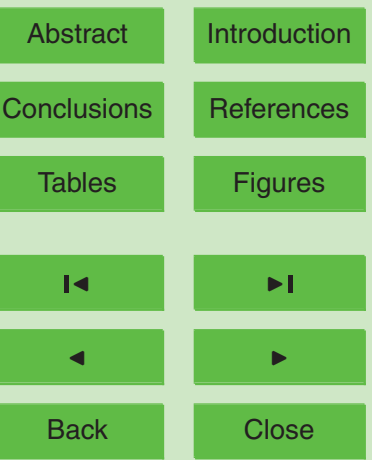

Full Screen / Esc

Printer-friendly Version

Interactive Discussion 


\section{HESSD}

6, 3089-3141, 2009

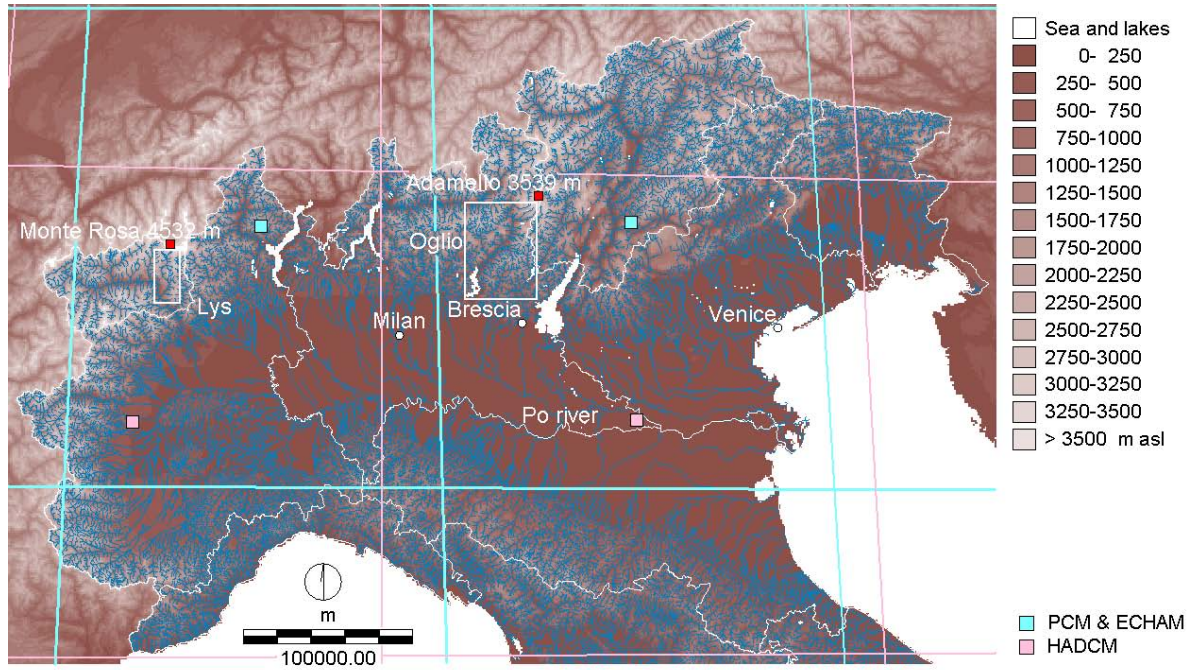

\section{Climate change and runoff regimes in the southern Alps}

S. Barontini et al.

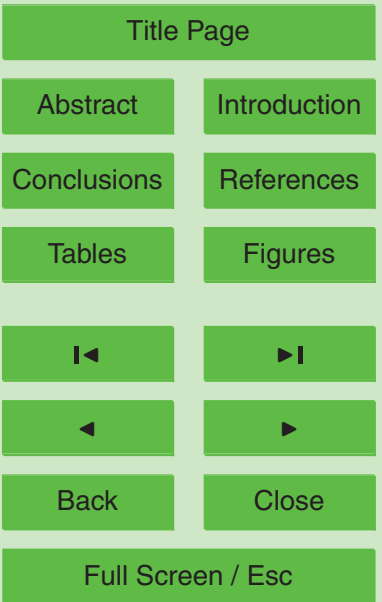

Fig. 1. Chorography of northern Italy: the white rectangules locate the investigated basins. PCM, ECHAM and HADCM central nodes and grids are represented.

Full Screen / Esc

Printer-friendly Version

Interactive Discussion 


\section{HESSD}

6, 3089-3141, 2009

1979-1999 TIME WINDOW

- Corrected observed precipitation regime - PCM precipitation regime

ECHAM precipitation regime $\square$ HADCM precipitation regime

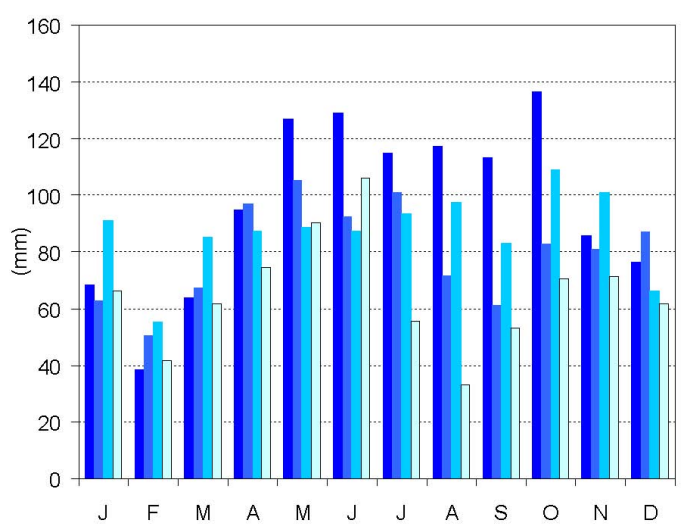

Future PCM scenarios

- 2040-2060 PCM precipitation regime (A2) 2079-2099 PCM precipitation regime (A2)

- 2040-2060 PCM precipitation regime (B2)

2079-2099 PCM precipitation regime (B2)

$\square$ 2079-2099 PCM precipitation regime (A1B)

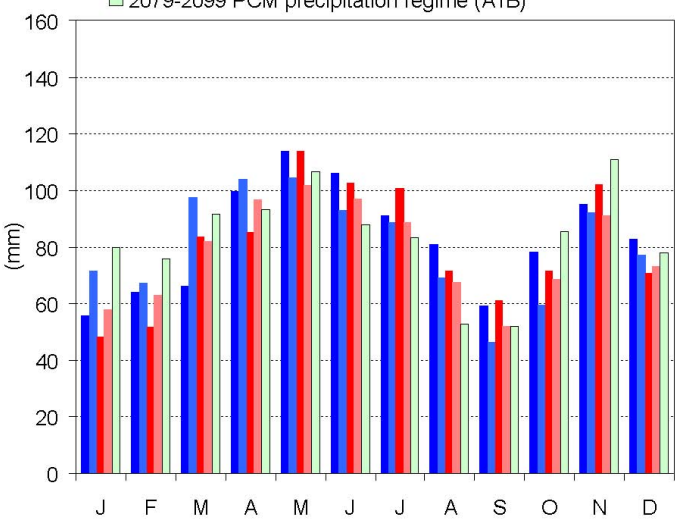

Climate change and runoff regimes in the southern Alps

S. Barontini et al.

\section{Title Page}

Abstract Introduction

Conclusions

References

Tables

Figures

14

$>$ I

4

Back

Close

\section{Full Screen / Esc}

Printer-friendly Version

Interactive Discussion 
HESSD

6, 3089-3141, 2009

Climate change and runoff regimes in the southern Alps
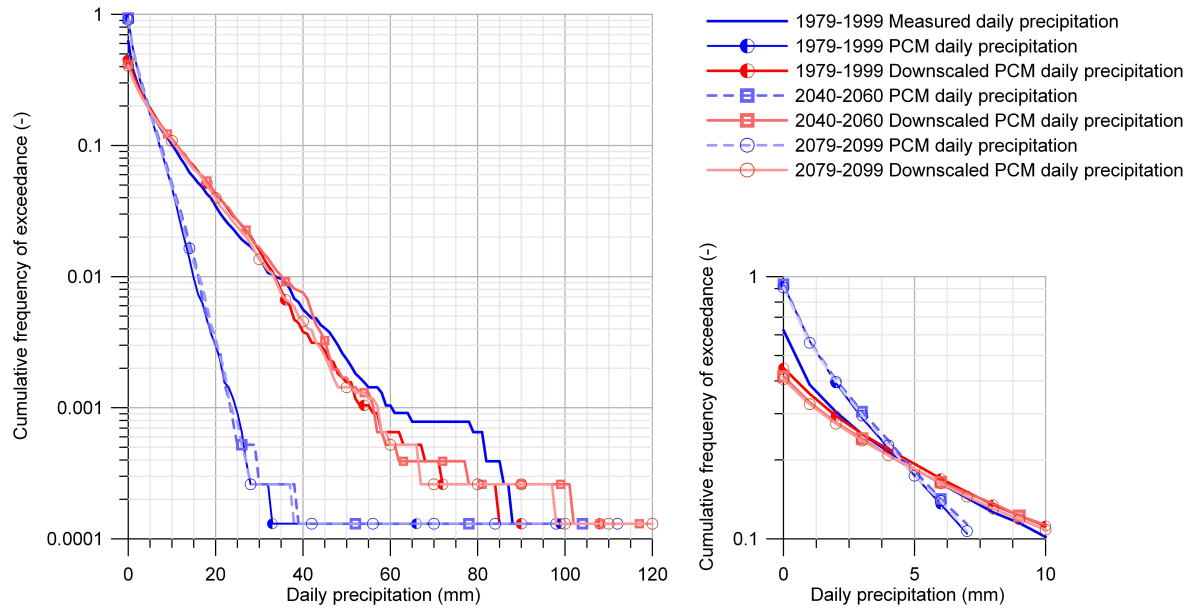

Title Page

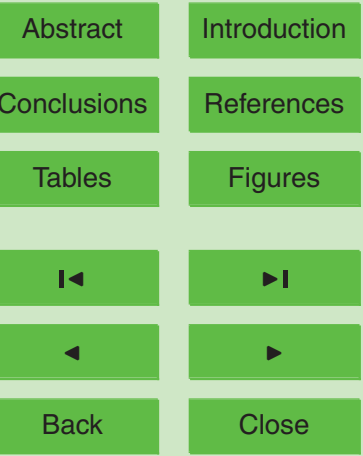

Full Screen / Esc

Printer-friendly Version

Interactive Discussion 


\section{HESSD}

6, 3089-3141, 2009

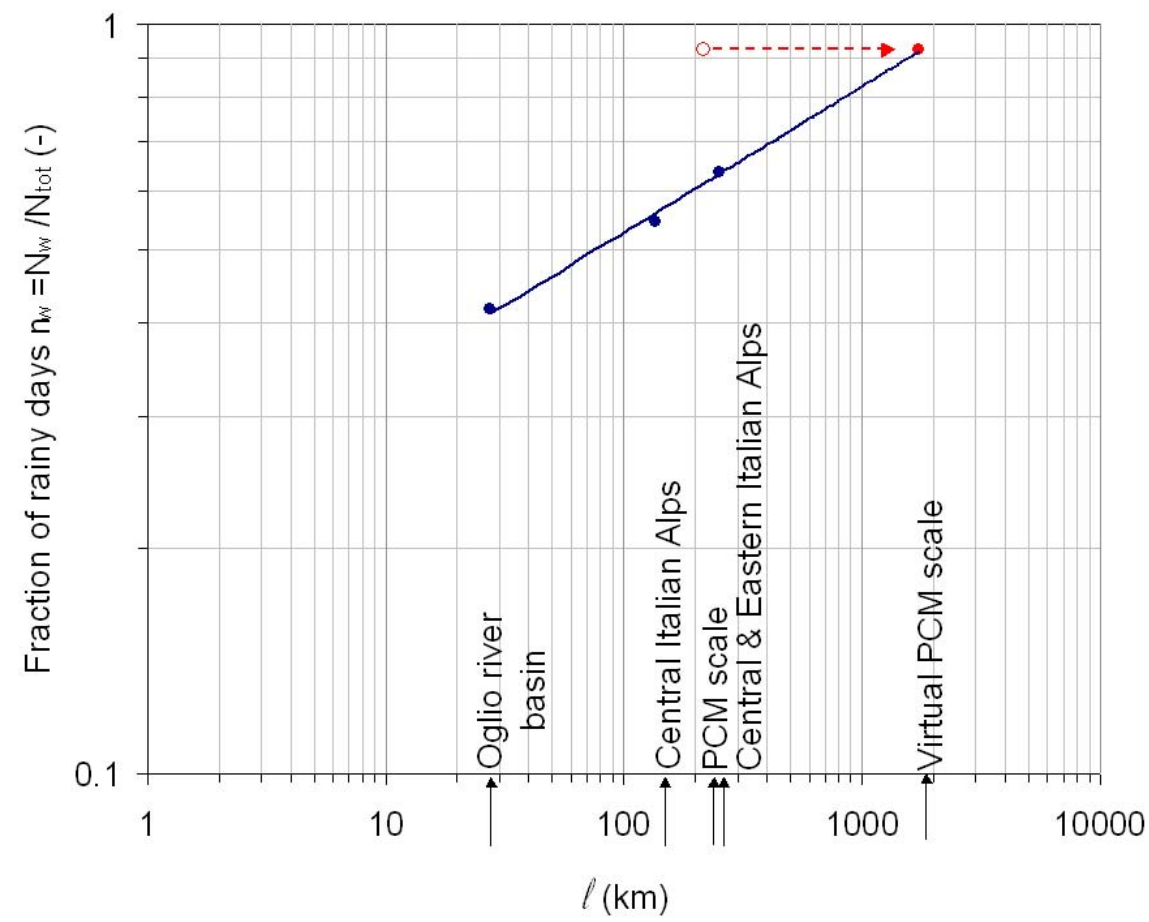

\section{Climate change and} runoff regimes in the southern Alps

S. Barontini et al.

Title Page

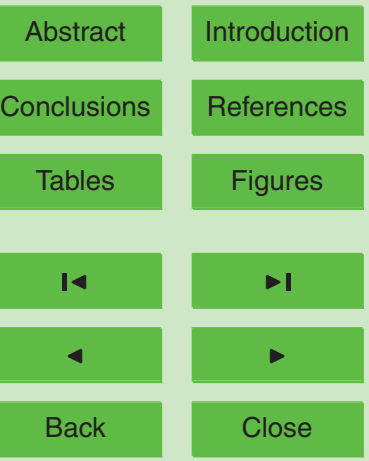

Full Screen / Esc

Fig. 4. Fraction of rainy days at different spatial scales $\ell$. The real and the virtual GCM scale (see Sect. 3.1.1 for details) are represented jointly to the experimental scales.

Printer-friendly Version

Interactive Discussion 


\section{HESSD}

6, 3089-3141, 2009

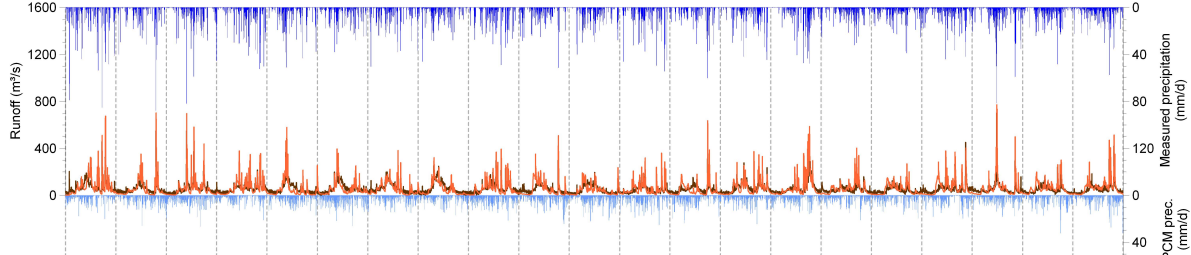

Climate change and runoff regimes in the southern Alps

S. Barontini et al.

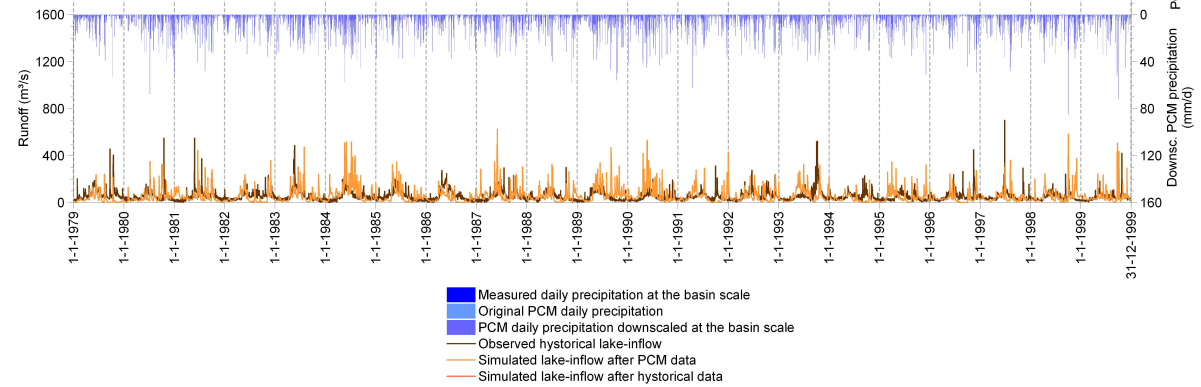

Title Page

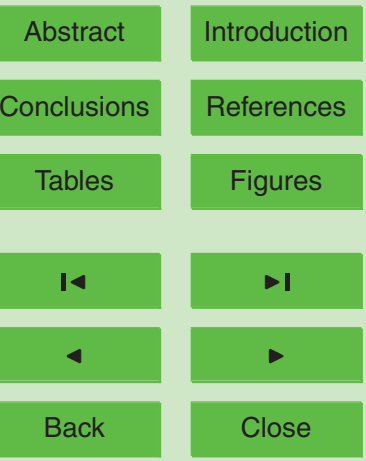

Fig. 5. Simulation of daily runoff with observed (above) and PCM (below) daily precipitation for the control period (1979-1999). Original (center) and downscaled PCM precipitation data are represented upside down.

\section{Full Screen / Esc}

Printer-friendly Version

Interactive Discussion 


\section{HESSD}

6, 3089-3141, 2009

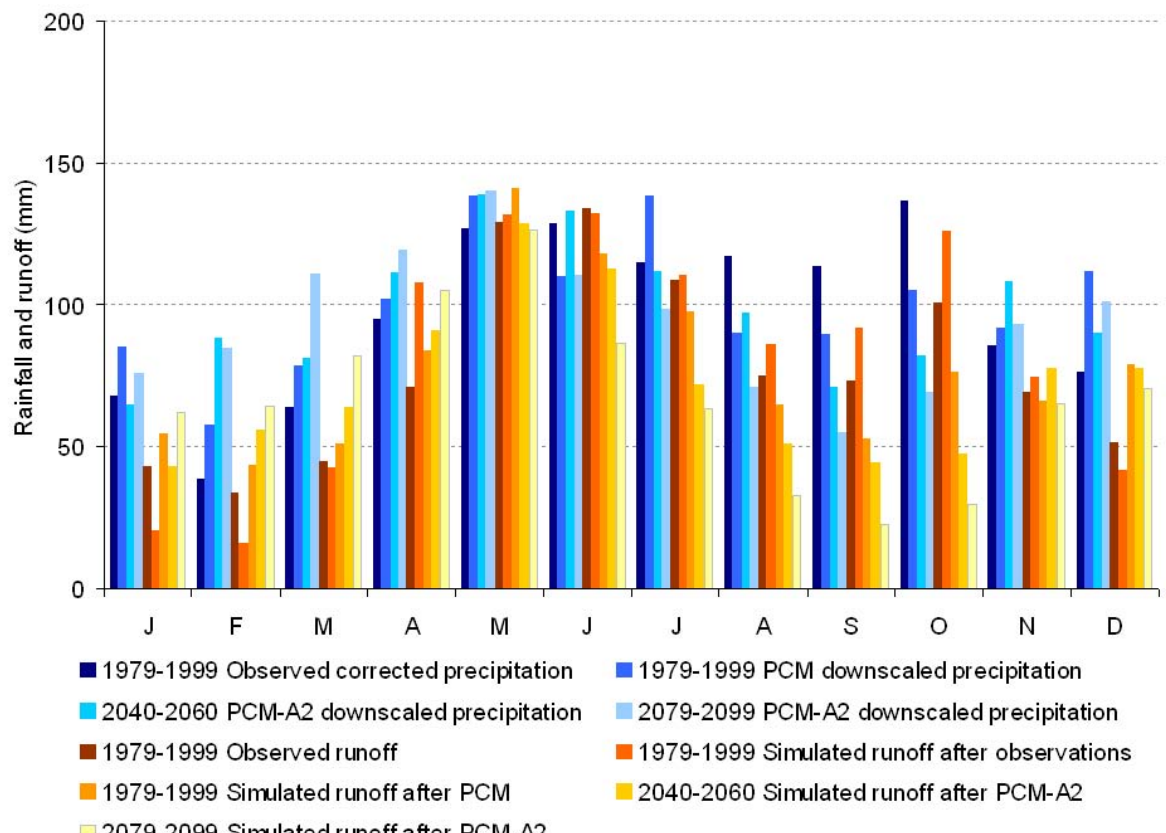

Climate change and runoff regimes in the southern Alps

S. Barontini et al.

\section{Title Page}

Abstract

Introduction

Conclusions

References

Tables

Figures

14

I

4

Back

\section{lose}

Full Screen / Esc

Printer-friendly Version

Interactive Discussion 


\section{HESSD}

6, 3089-3141, 2009

Climate change and runoff regimes in the southern Alps

S. Barontini et al.

\section{Title Page}

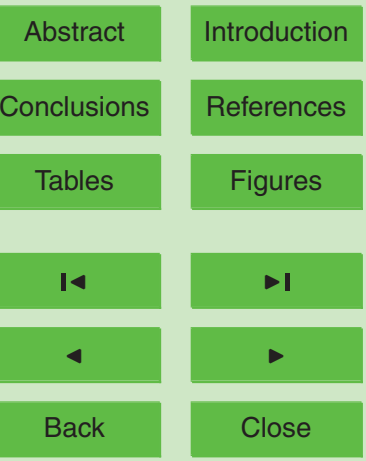

Full Screen / Esc

Printer-friendly Version

Interactive Discussion 